Prepared for the U.S. Department of Energy under Contract DE-AC05-76RL01830

\title{
Municipal Solid Waste (MSW) to Liquid Fuels Synthesis, Volume 1: Availability of Feedstock and Technology
}
C Valkenburg
MA Gerber
CW Walton
SB Jones
BL Thompson
DJ Stevens

December 2008

\section{Pacific Northwest}




\title{
DISCLAIMER
}

This report was prepared as an account of work sponsored by an agency of the United States Government. Neither the United States Government nor any agency thereof, nor Battelle Memorial Institute, nor any of their employees, makes any warranty, express or implied, or assumes any legal liability or responsibility for the accuracy, completeness, or usefulness of any information, apparatus, product, or process disclosed, or represents that its use would not infringe privately owned rights. Reference herein to any specific commercial product, process, or service by trade name, trademark, manufacturer, or otherwise does not necessarily constitute or imply its endorsement, recommendation, or favoring by the United States Government or any agency thereof, or Battelle Memorial Institute. The views and opinions of authors expressed herein do not necessarily state or reflect those of the United States Government or any agency thereof.

\author{
PACIFIC NORTHWEST NATIONAL LABORATORY \\ operated by \\ BATTELLE \\ for the \\ UNITED STATES DEPARTMENT OF ENERGY \\ under Contract DE-AC05-76RL01830
}

Printed in the United States of America
Available to DOE and DOE contractors from the Office of Scientific and Technical Information,

\footnotetext{
Available to the public from the National Technical Information Service, U.S. Department of Commerce, 5285 Port Royal Rd., Springfield, VA 22161 ph: (800) 553-6847 fax: (703) 605-6900 email: orders@ntis.fedworld.gov online ordering: http://www.ntis.gov/ordering.htm
} 


\title{
Municipal Solid Waste (MSW) to Liquid Fuels Synthesis, Volume 1: Availability of Feedstock and Technology
}

\author{
C Valkenburg \\ MA Gerber \\ CW Walton \\ SB Jones \\ BL Thompson \\ DJ Stevens
}

December 2008

Prepared for

the U.S. Department of Energy

under Contract DE-AC05-76RL01830

Pacific Northwest National Laboratory

Richland, Washington 99352 


\section{Executive Summary}

Municipal solid waste (MSW) is a domestic energy resource with the potential to provide a significant amount of energy to meet US liquid fuel requirements. MSW is defined as household waste, commercial solid waste, nonhazardous sludge, conditionally exempt, small quantity hazardous waste, and industrial solid waste. It includes food waste, residential rubbish, commercial and industrial wastes, and construction and demolition debris. It has an average higher heating value (HHV) of approximately $5100 \mathrm{btu} / \mathrm{lb}$ (as arrived basis).

According to the United States Environmental Protection Agency (EPA), the annual national MSW production in 2006 totaled more than $251 \mathrm{MM}$ short tons, which equates to greater than $4.5 \mathrm{lbs} /$ person/day. Of this total, about $45 \%$ is recovered via recycling, composting, and energy production. This leaves approximately $138 \mathrm{MM}$ short tons of unutilized MSW, which has about $1.4 \times 10^{15}$ Btu (1.4 quadrillion Btu) fuel value associated with it.

MSW has potential as a gasifier feedstock because it has a HHV (dry basis) that is nearly as high as most conventional biomass feedstocks. What makes it appealing as a potential feedstock is that it is readily available in the near-term having a pre-existing collection/transportation infrastructure and fee provided by the supplier that does not exist for conventional biomass resources.

This report investigated the potential of using MSW to make synthesis gas (syngas) suitable for production of liquid fuels. Issues examined include:

- MSW physical and chemical properties affecting its suitability as a gasifier feedstock and for liquid fuels synthesis

- expected process scale required for favorable economics

- the availability of MSW in quantities sufficient to meet process scale requirements

- the state-of-the-art of MSW gasification technology.

MSW is a heterogeneous feedstock containing materials with widely varying sizes and shapes and composition. This can be difficult to feed into many gasifiers and can lead to variable gasification behavior if used in an as received condition. It is expected that some minimal size reduction and sorting will need to be performed to make MSW suitable as a feedstock for MSW gasifiers. Refuse derived fuel (RDF) is a processed form of MSW where significant size reduction, screening, sorting, and, in some cases, pelletization is performed to improve the handling characteristics and composition of the material to be fed to a gasifier. The trade-off between the increased costs of producing RDF from MSW and potential cost reductions in gasifier design and operation are explored.

The chemical make-up of MSW includes significant quantities of chemical constituents that can create problems in downstream processes. While the concentrations of these contaminants are greater than that found in conventional biomass feedstocks, they are roughly comparable to those found in coal.

In order for MSW to be used for liquid fuels synthesis, it must be available in sufficient quantities to meet the necessary process scale for favorable economics. Using a previous economic study on liquid fuels synthesis from gasification of wood, the expected process scale could by as much as 3,300 short 
tons per day (as arrived basis). However, the economics associated with MSW are very different from conventional biomass feedstocks. Whereas conventional biomass costs about $\$ 44 /$ dry ton to purchase as a feedstock, landfills around the country using incinerators and gasifiers to produce electric power from MSW charge about $\$ 30 /$ ton (as received) additional tipping fee beyond that typically charged to just landfill the material. By charging this additional tipping fee, it may be possible to achieve favorable economics for liquid fuels synthesis at a much smaller scale.

This study identified 47 landfill sites around the country that processed 3300 short tons per day or more of MSW (as arrived basis). Together these sites could produce more than 310,000 bbl per day of liquid fuels (as fuel grade ethanol), which is equal to about $1.4 \%$ of current U.S. transportation fuels demand. This would double if plants as small as 1250 short tons per day were found to be economical with appropriate tipping fees. This study (and others) identified that United States MSW landfills receive more than double the mass of material estimated using values reported by the EPA. Reasons for this discrepancy are discussed.

This study also identified four commercially available and two demonstration MSW gasifiers, two of which involved co-feeding with coal. Three of these gasifiers were used to produce electricity and process heat and consequently were close coupled to combustors and would need to be modified to produce syngas. The other three gasifiers were capable of producing syngas or fuel gas, and would not require modification. There were also a large number of other MSW gasifiers under development that may ultimately be suitable for syngas applications.

Overall, this study concludes that MSW should be considered as a potentially viable gasifier feedstock for liquid fuels synthesis. A review of feedstock availability, composition, and handling characteristics along with commercially available MSW specific gasifiers did not identify any obvious insurmountable technical or economic barriers to commercialization. However, further research into the economic issues surrounding tipping fees and process scale is needed to verify economic viability and the appropriate plant scale to achieve it. 


\section{Acknowledgments}

This report is a survey of the information available on municipal solid waste and biomass gasification as a pathway for synthesis of liquid fuel. The authors did extensive research to locate the information as listed in the Reference section of this document. Sources for all data shown in figures and tables are referenced within the text. Tables and figures not generated by the authors come from their identified source. 


\section{Acronyms and Abbreviations}

$\begin{array}{ll}\text { EPA } & \text { U.S. Environmental Protection Agency } \\ \text { Ecology } & \text { Washington State Department of Ecology } \\ \text { MSW } & \text { Municipal Solid Waste } \\ \text { Btu } & \text { British thermal unit } \\ \text { MJ } & \text { Megajoule } \\ \text { MM } & \text { Million } \\ \text { kg } & \text { Kilogram } \\ \text { RDF } & \text { Refuse Derived Fuel } \\ \text { bbl } & \text { Barrels } \\ \text { LFG } & \text { Landfill Gas }\end{array}$




\section{Contents}

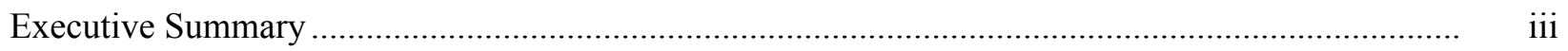

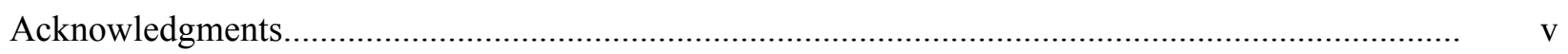

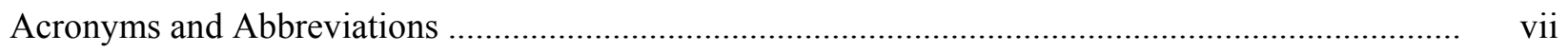

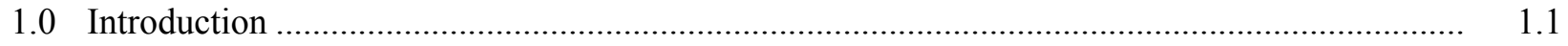

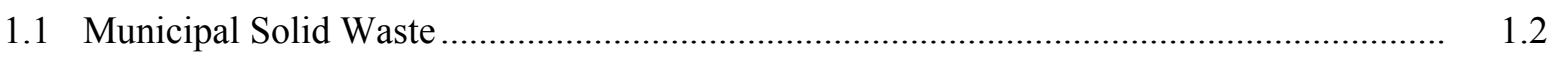

2.0 Refuse Derived Fuel ......................................................................................... 2.1

3.0 MSW's Suitability for Gasification into a Synthesis Gas for Liquid Fuels Production .............. 3.1

3.1 MSW Feedstock Quality Issues .............................................................................

3.2 Economic Issues Affecting MSW Suitability as a Feedstock .......................................... 3.5

4.0 Availability and Distribution of MSW .......................................................................... 4.1

5.0 Current State of Gasification Technology .................................................................. 5.1

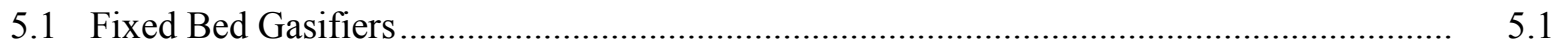

5.2 Fluidized Bed Gasifiers ........................................................................................ 5.3

5.3 Entrained Flow Gasifiers............................................................................... $\quad 5.5$

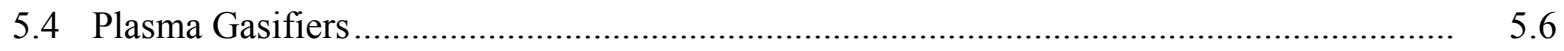

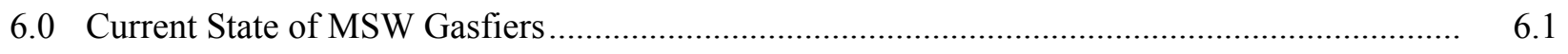

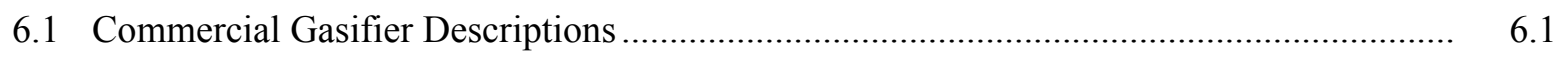

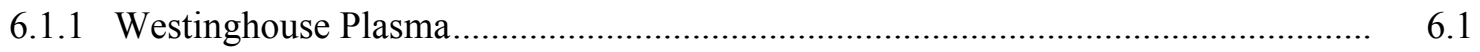

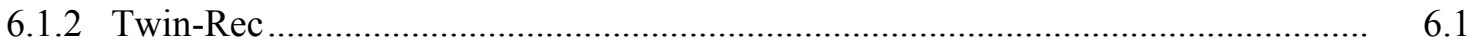

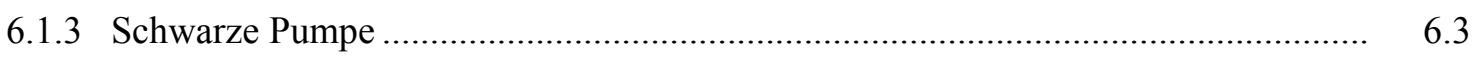

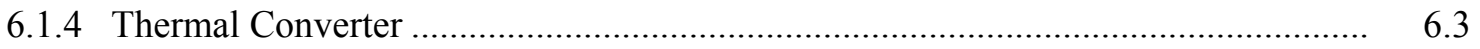

6.2 Demonstration Gasifier Descriptions ......................................................................... 6.3

6.2.1 High Temperature Winkler Gasifier............................................................ 6.3

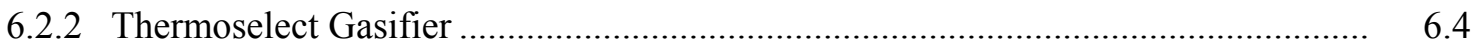

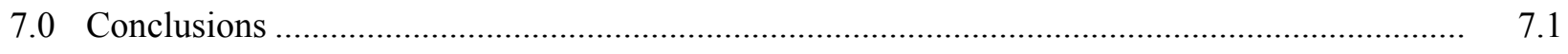

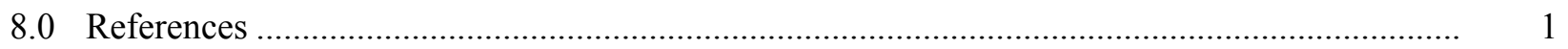




\section{Figures}

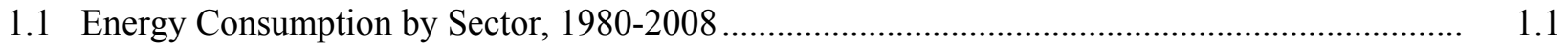

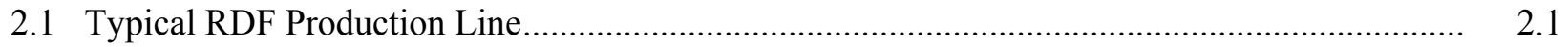

3.1 Comparison of RDF and MSW with Conventional Gasifier Fuels........................................ 3.2

3.2 Heating Value Comparison of RDF and MSW with Conventional Gasifier Fuels .................... 3.2

3.3 Variation of Heating Values of Solid Waste Components as a Function of Moisture Content.... 3.3

3.4 Elemental Comparison of RDF and MSW with Conventional Gasifier Fuels .......................... 3.5

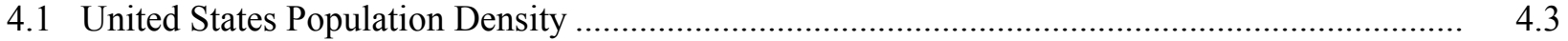

4.2 Number of Landfills, Nation-Wide, Since 1988 .......................................................................

4.3 U.S. Landfills Receiving $\geq 3300$ Short Tons per Day ......................................................... 4.4

4.4 Throughput Distribution Processed by the Nation's Active Municipal Solid Waste Landfills .... 4.5

5.1 Simplified Schematic of an Up-Draft, Fixed-Bed Gasifier..................................................... 5.2

5.2 Simplified Schematic of a Down-Draft, Fixed-Bed Gasifier................................................... 5.3

5.3 Simplified Schematic of a Fluidized Bed Gasifier.................................................................. 5.4

5.4 Simplified Schematic of a Circulating, Fluidized Bed Gasifier................................................... 5.4

5.5 Simplified Schematic of an Entrained Flow Gasifier ............................................................. 5.5

5.6 Simplified Schematic of a Plasma Gasifier............................................................................ 5.6

\section{Tables}

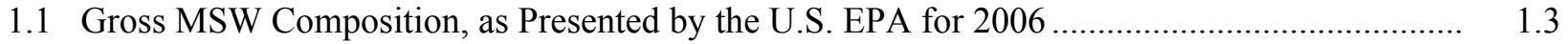

1.2 Example MSW Characterization Table …............................................................................ 1.5

3.1 Elemental Composition of Bulk MSW .............................................................................. 3.4

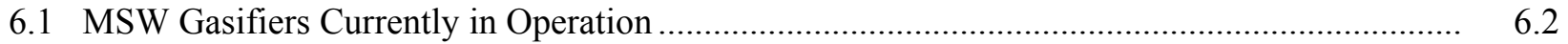




\subsection{Introduction}

The United States produces the largest amount of municipal solid waste (MSW) per capita in the world. The United States Environmental Protection Agency (EPA) estimated that the national MSW production totaled more than $251 \mathrm{MM}$ short tons in 2006, before recycling, which equates to greater than $4.5 \mathrm{lbs} /$ person/day. For perspective, assume an average heating value of $5100 \mathrm{Btu}$ per pound of MSW. Approximately $2.5 \times 10^{15}$ Btu (2.5 quadrillion Btu) per year would then be associated with the U.S. MSW stream. Energy Information Administration (EIA) estimates for total U.S. energy consumption, broken into the major sectors for 1980 to 2008 is shown in Figure 1.1 for comparison (DOE/EIA 2008). The heating value of the EPA's estimated national MSW stream is equal to $21 \%, 29 \%, 8 \%$, and $10 \%$ of the EIA's estimates for residential, commercial, industrial, and transportation sector's energy consumption, respectively, or more than 3\% of EIA's estimate for total U.S. energy demand.

\section{Energy Consumption by Sector 1980-2008 (Quadrillion Btu)}

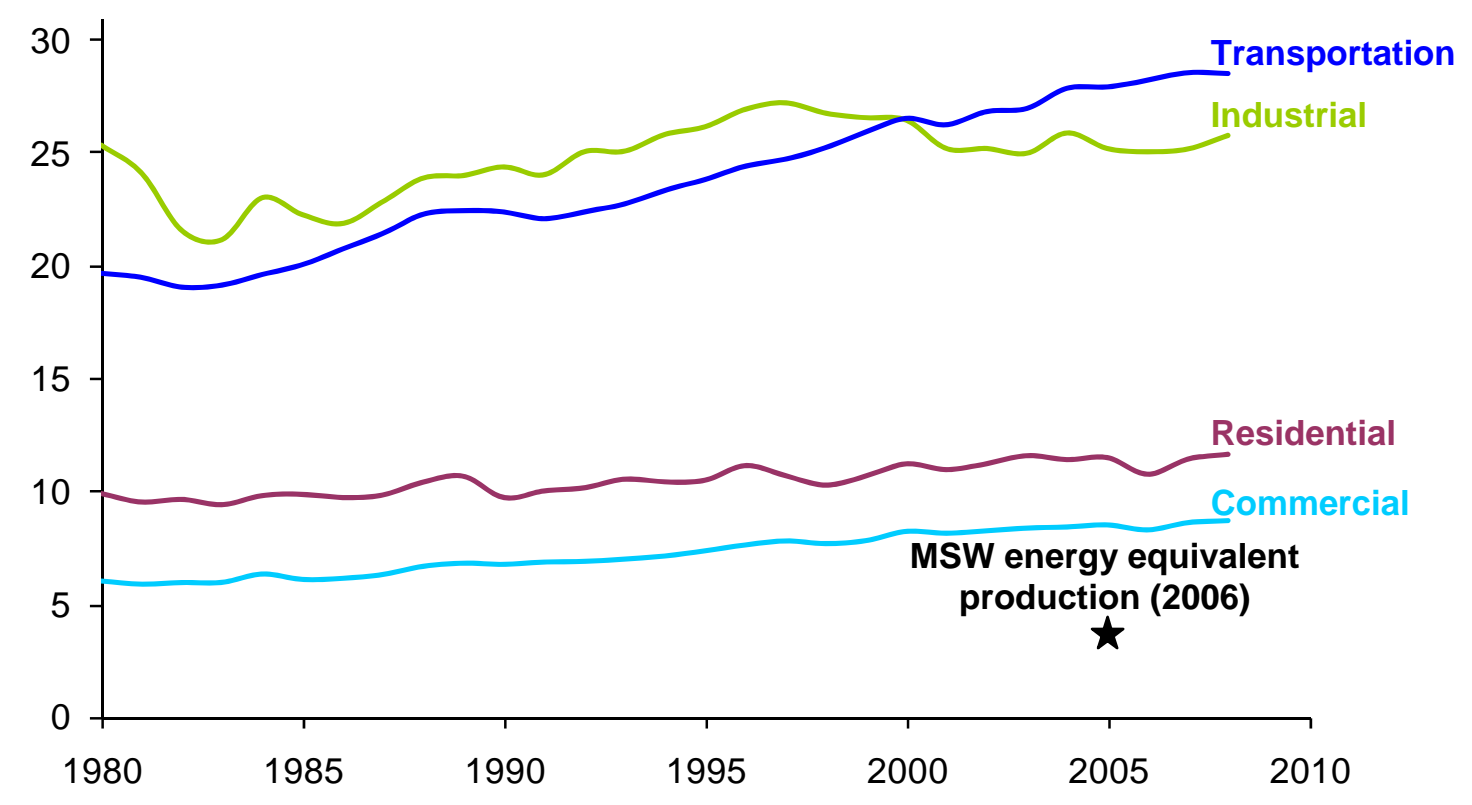

Figure 1.1. Energy Consumption by Sector, 1980-2008

Not all of this material may be considered to be available. The EPA reported that recycling (including composting) and waste-to-energy facilities diverted $113 \mathrm{MM}$ short tons from landfill disposal in 2006. Therefore, a more realistic approximation may be that $55 \%$ of the U.S. MSW stream is available for conversion. Using the same assumptions for heating value and EIA estimates for energy demand, the heating value of the theoretically available MSW stream would be equivalent to $11 \%, 16 \%, 4 \%$, and $5 \%$ of the nation's residential, commercial, industrial, and transportation sectors, respectively. This interpretation is a straight comparison of the heating value associated with the EPA's estimates for landfilled MSW with energy demand and does not include any loss in efficiency associated with conversion to any particular fuel (e.g., power, liquids). 
While the estimated energy content of MSW currently entering landfills is a small fraction of the total amount of energy consumed by the U.S., recent studies show that the organic fraction of MSW represents a significant resource when compared to biomass fuels currently available for conversion to energy. For example, MSW accounts for $70 \%$ of the carbonaceous resource (including MSW and biomass) currently available in areas such as Oregon and Washington (Stiles et al. 2008). Since the major fraction of MSW consists of biomass materials, utilization of MSW also provides environmental benefits, such as reduction of green house gas emissions $\left(\mathrm{CO}_{2}, \mathrm{CH}_{4}\right)$ and landfill space, as well as reduced environmental hazards potential associated with soil and water contamination and unplanned fires at landfills.

Conventional incineration (and gasification) technologies, often referred to as "waste-to-energy" technologies, are currently used in some states to generate power and heat. Gasification technologies enable conversion of MSW into value added products, such as liquid fuels and commodity chemicals, as well as electricity, and do so at greater efficiencies than conventional incineration (Stevens 1994, Klass 1998, Rezaiyan and Cherenmisinoff 2005). This report considers the nation's MSW as a potential carbonaceous feedstock for conversion to fuels and chemicals. An initial assumption is that the MSW infrastructure (e.g., collection, transportation), already in place, makes landfills ideal locations for nearterm alternative fuel synthesis technologies. The latest developments in gasification that are key to alternative fuel synthesis are also reviewed.

\subsection{Municipal Solid Waste}

Municipal solid waste is defined as household waste, commercial solid waste, nonhazardous sludge, conditionally exempt, small quantity hazardous waste ${ }^{1}$, and industrial solid waste (EPA-530-R-95-023 1995). MSW includes food waste, rubbish from residential areas, commercial and industrial wastes, and construction and demolition debris. Biosolids (byproducts from waste water treatment, also known as sewage sludge) are not included in the formal definition of MSW, though it is estimated that 20 percent of the $8 \mathrm{MM}$ dry short tons of biosolids generated annually are handled by MSW landfills (EPA-530-R-99009 1999, EPA-832-R-06-005 2006).

Gross MSW composition is typically documented under the categories of "Products" and "Other Wastes". The "Products" category includes paper, glass, metal, plastic, rubber and leather, textiles, wood, and other materials generated by the consumer market. "Other Wastes" includes food, yard trimmings, and other organic wastes. Defining these particular subcategories assists reporting agencies, such as the EPA, in setting benchmarks for landfill diversions (e.g., recycling, composting, and waste-to-energy). Table 1.1 shows MSW generation rates for 2006 (EPA-530-F-07-030 2007).

\footnotetext{
${ }^{1}$ Conditionally exempt, small quantity hazardous waste is defined by the EPA as 220 pounds (or less) of hazardous wastes per calendar month, or 2.2 pounds (or less) of acute hazardous wastes per calendar month, or 220 pounds (or less) of spill cleanup debris containing hazardous waste per calendar month.
} 
Table 1.1. Gross MSW Composition, as Presented by the U.S. EPA for 2006

\begin{tabular}{|c|c|c|}
\hline Materials & $\begin{array}{l}\text { Mass Generated } \\
\text { (MM sTon) }\end{array}$ & $\begin{array}{c}\text { Percent of } \\
\text { Total } \\
\text { Generation }\end{array}$ \\
\hline Paper and Paperboard & 85.3 & 33.9 \\
\hline Glass & 13.2 & 5.3 \\
\hline \multicolumn{3}{|l|}{ Metals } \\
\hline Ferrous & 14.2 & 5.7 \\
\hline Aluminum & 3.26 & 1.3 \\
\hline \multirow[t]{2}{*}{ Other Nonferrous } & 1.65 & 0.7 \\
\hline & 19.1 & 7.6 \\
\hline Plastics & 29.5 & 11.7 \\
\hline Rubber and Leather & 6.54 & 2.6 \\
\hline Textiles & 11.8 & 4.7 \\
\hline Wood & 13.9 & 5.5 \\
\hline Other Materials & 4.55 & 1.8 \\
\hline Total Materials in Products: & 164.79 & 73.2 \\
\hline \multicolumn{3}{|l|}{ Other Wastes } \\
\hline Food Scraps & 31.3 & 12.4 \\
\hline Yard Trimmings & 32.4 & 12.9 \\
\hline Miscellaneous Inorganic Wastes & 3.72 & 1.5 \\
\hline Total Other Wastes: & 67.42 & 26.8 \\
\hline Total MSW: & 251.31 & 100 \\
\hline
\end{tabular}

The generation rates given in Table 1.1 are compiled using a materials flow methodology (Franklin Associates 2008). In other words, it is assumed that all materials produced are eventually recycled, combusted, or disposed of. Production rates are obtained from "industry associations, key businesses, and similar industry sources" (EPA 2008). Adjustments are made to account for lifetimes of products, the import/export of materials, wastes and other "diversions" (EPA 2008). The database and its corresponding model have been developed and refined over the last 40 years (Franklin Associates 2008) and are a reasonable approach to estimating national MSW generation rates. This top-down approach leads to a total of $251 \mathrm{MM}$ short tons of waste generated, with $82 \mathrm{MM}$ short tons recycled and $31 \mathrm{MM}$ short tons used for waste-to-energy in 2006. A first approximation is that the left-over mass, $138 \mathrm{MM}$ short tons, entered the nation's landfills that year.

The materials flow methodology is appropriate for establishing national MSW trends by which recycling (and other diversions) may be compared and targets established. However, this methodology does not yield enough details for determining the feasibility of using MSW for conversion to liquid fuels or chemicals, nor does it provide MSW distribution information specific to a given region. Published EPA MSW "generation rates" differ from the rates at which the entirety of waste components actually enters the waste stream infrastructure. For example, values given in Table 1.1 do not include construction and demolition (C\&D) debris, industrial process wastes, or certain other wastes entering landfills through this infrastructure. C\&D lumber, alone, is reported to comprise as much as 10 percent of the bone dry MSW stream in states like California and Washington (California Biomass Collaborative 2006, 
Ecology 2006). Non-MSW wastes entering the nation's landfills results in local and state governments reporting MSW rates that are more than double the amount published by the EPA.

A regional waste characterization study such as the one found for California (340-04-05 2004) should be used to define the gross biomass, other organic, and inorganic fractions of that waste stream. A bottom-up analysis approach is essential for capturing all of the waste stream components. Databases providing compositional data for biomass and waste materials (Phyllis 2008) are available to aid the assessor in evaluating a potential conversion stream by incorporating ash, moisture, and heating value into the facility siting and economic assessments. By using these types of information, a table more amenable to assessing MSW conversion opportunities can be prepare as was the information for California shown in Table 1.2, in which quantities produced, heating values, and inorganic fractions are clearly defined for key categories of waste. 
Table 1.2. Example MSW Characterization Table (California Biomass Collaborative 2006)

\begin{tabular}{|c|c|c|c|c|c|c|c|c|c|}
\hline Material & $\begin{array}{l}\text { Landfilled Mass, } \\
\text { wet (MM sTon) }\end{array}$ & $\begin{array}{l}\% \text { of Total } \\
\text { (wet) MSW }\end{array}$ & $\begin{array}{c}\text { Moisture } \\
\text { Content } \\
\text { (wt.\%) }\end{array}$ & $\begin{array}{l}\text { Landfilled } \\
\text { Mass } \\
\text { (MM BDT) }\end{array}$ & $\begin{array}{c}\text { Ash } \\
\text { (wt.\%,dry) }\end{array}$ & $\begin{array}{c}\text { Ash } \\
\text { (MM sTon) }\end{array}$ & $\begin{array}{c}\mathrm{HHV} \\
\text { (MJ/kg dry) }\end{array}$ & $\begin{array}{c}\mathrm{HHV} \\
\text { (MJ/kg daf.) }\end{array}$ & $\begin{array}{c}\mathrm{HHV} \\
(\mathrm{MJ} / \mathrm{kg} \text { ar) }\end{array}$ \\
\hline \multicolumn{10}{|l|}{ Biomass } \\
\hline Paper/Cardboard & 9.1 & 21.0 & 5.2 & 8.7 & 7.9 & 0.7 & 21.2 & 23.1 & 20.1 \\
\hline Food & 6.4 & 14.6 & 36.6 & 4.0 & 5.4 & 0.2 & - & 23.7 & - \\
\hline Leaves and Grass & 1.8 & 4.2 & 43.4 & 1.0 & 9.2 & 0.1 & - & 19.6 & - \\
\hline Other Organics & 1.9 & 4.4 & 26.4 & 1.4 & 10.6 & 0.1 & - & 20.9 & - \\
\hline C\&D Lumber & 4.2 & 9.6 & 12.9 & 3.6 & 9.9 & 0.4 & - & 20.4 & - \\
\hline Prunings and Trimmings & 1.0 & 2.3 & 31.0 & 0.7 & 6.8 & 0.0 & - & 19.6 & - \\
\hline Branches and Stumps & 0.1 & 0.3 & 46.7 & 0.1 & 3.2 & 0.0 & 20.8 & 21.5 & 11.1 \\
\hline Total Biomass Carbon Compounds: & 24.5 & 56.4 & 28.9 & 19.5 & 7.6 & 1.6 & 21.0 & 21.2 & 15.6 \\
\hline \multicolumn{10}{|l|}{ Other Organics } \\
\hline All non-Film Plastic & 2.2 & 5.1 & 0.2 & 2.2 & 2.3 & 0.1 & 41.9 & 42.9 & 41.8 \\
\hline Textiles & 1.9 & 4.3 & 13.5 & 1.6 & 16.2 & 0.3 & 21.9 & 26.1 & 18.9 \\
\hline Film Plastic & 1.9 & 4.4 & 0.2 & 1.9 & 0.1 & 0.0 & 40.6 & 40.7 & 40.6 \\
\hline Total Non-Biomass Carbon Compounds: & 6.0 & 13.8 & 4.6 & 5.7 & 6.2 & 0.3 & 34.8 & 36.6 & 33.8 \\
\hline \multicolumn{10}{|l|}{ Inorganic } \\
\hline Other C\&D & 5.3 & 12.1 & - & 5.3 & 100.0 & 5.3 & - & - & - \\
\hline Metal & 3.3 & 7.7 & - & 3.3 & 100.0 & 3.3 & - & - & - \\
\hline Other Mixed and Mineralized & 3.3 & 7.7 & - & 3.3 & 100.0 & 3.3 & - & - & - \\
\hline Glass & 1.0 & 2.3 & - & 1.0 & 100.0 & 1.0 & - & - & - \\
\hline Total Mineral: & 13.0 & 29.8 & - & 13.0 & & 13.0 & - & - & - \\
\hline Total Landfilled MSW: & 43.5 & 100.0 & 21.6 & 38.2 & 33.7 & 14.8 & 29.3 & 25.8 & 26.5 \\
\hline
\end{tabular}




\subsection{Refuse Derived Fuel}

Refuse derived fuel (RDF) is defined as the product of a mixed waste processing system in which certain recyclable and non-combustible materials are removed with the remaining combustible material converted for use as a fuel to create energy (EPA-530-R-95-023 1995). Typical RDF processing includes ferrous material removal, shredding, screening, crushing, and even eddy-current separation or air classification for aluminum recovery. Some operations further grind/shred, and mix material to generate a homogeneous fuel. It is also common for processors to press and extrude the material into pellets.

On average, $75 \%-85 \%$ of the weight of MSW is converted into RDF and approximately $80 \%-90 \%$ of the BTU value is retained. This leaves RDF with a higher heating value of 4,800-6,400 Btu/lb, which is approximately half of the Btu value of the same weight of coal (NREL/TP-431-4988A 1992). The main benefits of converting MSW to RDF are a higher heating value, more homogeneous physical and chemical compositions, lower pollutant emissions, reduced excess air requirement during combustion, and finally, easier storage, handling, and transportation.

The mass balance and quality of the end product are heavily affected by the type, number, and position of the equipment for these steps. Figure 2.1 illustrates a typical line configuration for a RDF production train. Shredders typically use hammers running at high speeds to chop and shred the waste. Trommel screens are rotating, tubular vessels used for sorting the waste by size. Eddy current separators use induced magnetic fields to create repelling forces that eject non-ferrous metals into a bin separate from the remaining materials. The magnetic separator uses magnets to remove ferrous metals that can ultimately be recycled. Finally, mills (again, often hammer mills) shred the material into fine particles. Additional stages can be included at various points in the system including hand sorting and air classification. Air classification, when used, can separate glass from metal free MSW.

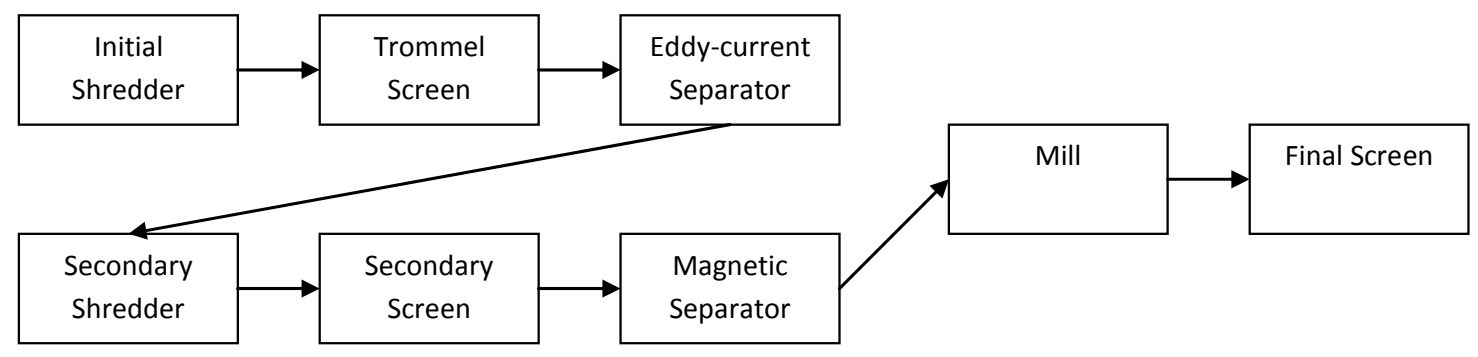

Figure 2.1. Typical RDF Production Line

The process flow diagram shown in Figure 2.1 yields a low-density product fuel known as fluff. Densifiers or pelletizers are commonly added at the end of a system to generate an easily stored and transported fuel. Due to the large variance in RDF production lines, the efficiency of the process as well as the heating value of the product varies. The production line illustrated in Figure 2.1 has a mass efficiency (i.e., ratio of produced RDF mass to inlet waste mass) of approximately $24 \%$. Note that typical mass efficiencies are reported to range from 18\%-31\% (Caputo and Pelagagge 2001). On average, 0.031-0.046 MM Btu per short ton of MSW is required for RDF production (NREL/TP-431-4988A 1992). The value would be somewhat higher when the RDF is further pelletized, creating a trade-off between improved material handling properties and energy expended to make the pelletized product. 


\subsection{MSW's Suitability for Gasification into a Synthesis Gas for Liquid Fuels Production}

The suitability of MSW for gasification into a synthesis gas for liquid fuels production depends on the quality of MSW both as a feedstock for a gasifier and in terms of the gas cleanup requirements needed to removing impurities from the gas that that can cause problems in downstream processes, and the overall economics of the process. The latter is important because it generally dictates the minimum scale for the process.

\subsection{MSW Feedstock Quality Issues}

The quality of MSW as a feedstock to a gasification process is important in terms of gasifier design requirements to handle the feedstock and gas cleanup equipment needed to remove contaminants in the gas leaving the gasifier that can be detrimental to down-stream catalytic processes. The physical characteristics of MSW have a direct effect on gasification in terms of the degree of difficulty of feeding MSW into a gasification vessel and removing ash and other tramp inorganic material from the vessel. Conventional biomass gasifiers use biomass feedstocks that have been chipped or hammer milled into a size that can be auger-fed into the gasifier. Ash produced during gasification is either removed as fly ash from the product gas using cyclones or filters, or is removed from the bottom of the gasifier vessel using another auger. MSW contains materials ranging in size from dusts and liquids to large objects made of metal, plastic, wood and/or other materials as indicated in Tables 1.1 and 1.2. In order to use MSW as a feedstock, it either needs to be reduced in size so that it can be fed into a gasifier using an auger, or the gasifier feed system needs to be designed handle larger objects. In either case, some minimal processing is usually needed to remove very large objects made of inorganic materials. If relatively large inorganic objects are fed into the gasifier, provisions must be made in the gasifier design for removal of large pieces of inorganic materials from the bottom of the gasifier along with more conventional fine ash. Sorting processes may be used to remove very large objects and some minimal size reduction via shredding or compaction to provide a more manageable feedstock. As was previously discussed, one of the purposes of making RDF from MSW is to produce a feedstock that is more amenable to conventional biomass feeder systems. Any processing of the MSW to produce a more easily handled material will add cost to the overall gasification process, creating an economic trade-off between feed preparation costs and gasifier capital and operating costs.

The chemical composition of MSW also has an impact on its suitability as a gasifier feedstock. As previously discussed, both MSW and RDF contain a significant amount of inorganic material. Figure 3.1 shows a comparison of MSW and RDF to more conventional biomass feedstocks and coal (Phyllis 2008). It can be seen that both MSW and RDF have ash contents that are much higher that other biomass feedstocks and about 30\% higher than coal. MSW also has a much greater water content than the other biomass and coal feedstocks, while RDF has a water content that is more comparable to the other feedstocks. High ash and water content in MSW feedstocks is detrimental because it dilutes its higher heating value (HHV) as shown in Figure 3.2 (HHV comparison on an as received (ar) basis) (Phyllis 2008). In addition to diluting the heating value of the feedstock, water also creates an energy burden to the overall process in order to dry the feedstock prior to gasifying it. RDF, because of its lower moisture content, has a higher as received HHV than MSW even though their ash content is nearly the same. Figure 3.2 shows that on a dry basis both MSW and RDF have HHVs that are comparable to the other 
forms of biomass. Interestingly, on a dry ash free basis (daf), both MSW and RDF have higher HHVs than the other forms of biomass, due to its higher content of non-biomass derived organic materials such as plastics and rubber. This is further illustrated in a graph based on New York City solid wastes, by Themelis et al. (2002), shown in Figure 3.3.

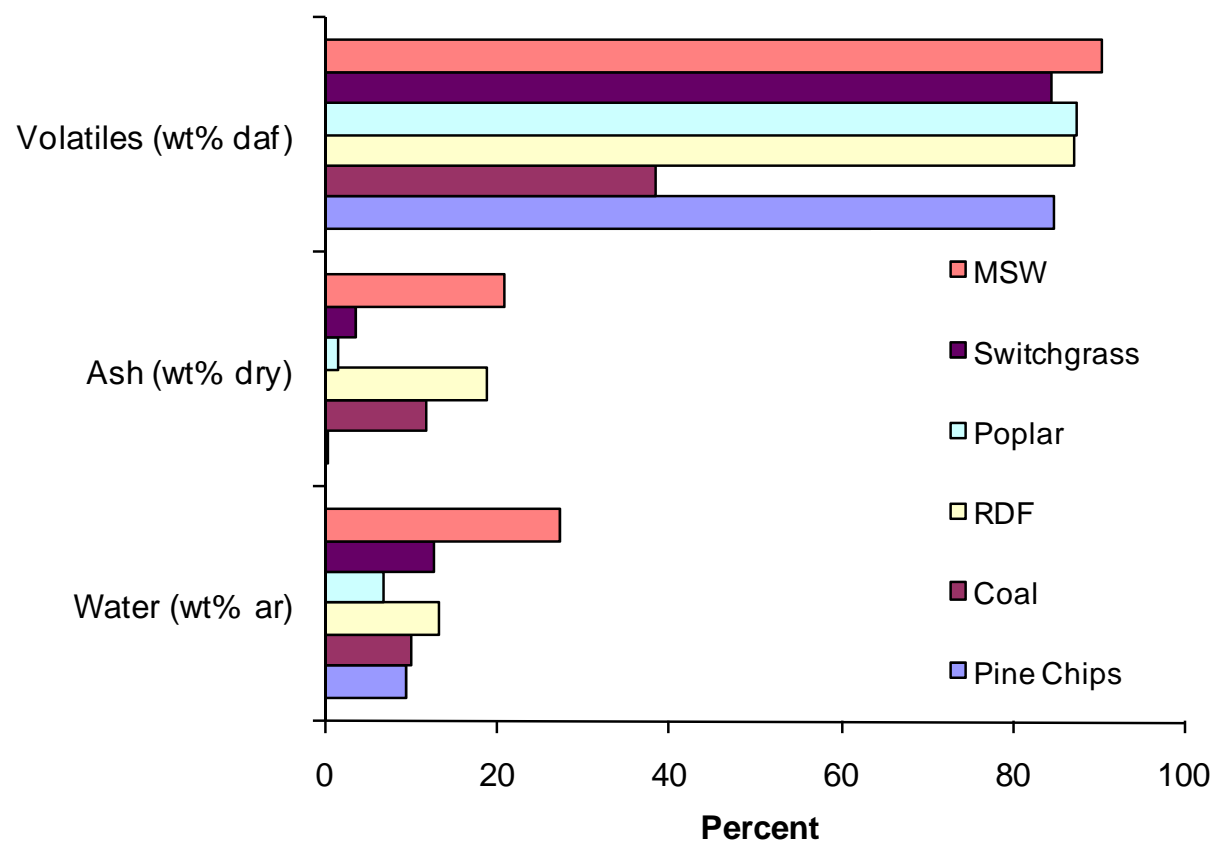

Figure 3.1. Comparison of RDF and MSW with Conventional Gasifier Fuels

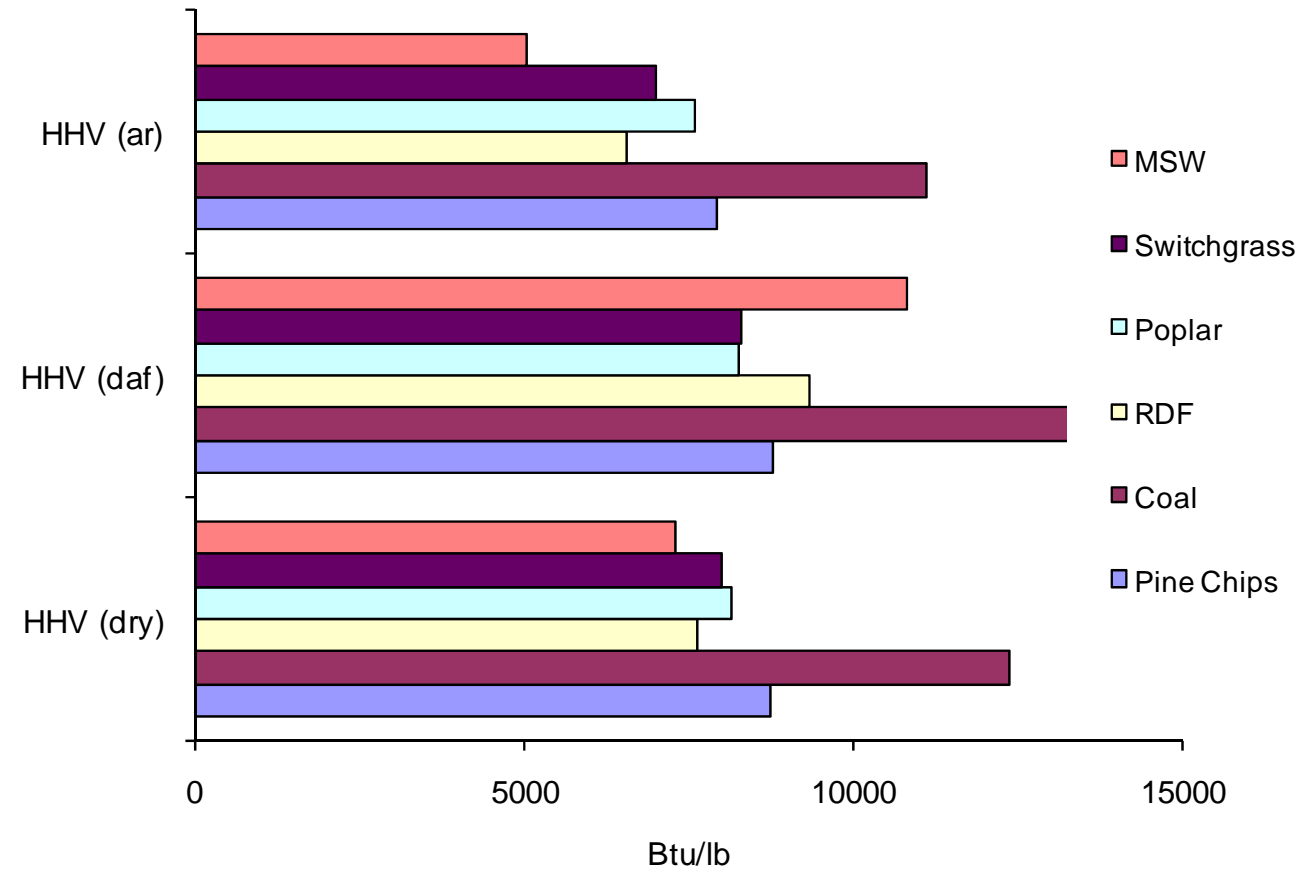

Figure 3.2. Heating Value Comparison of RDF and MSW with Conventional Gasifier Fuels 


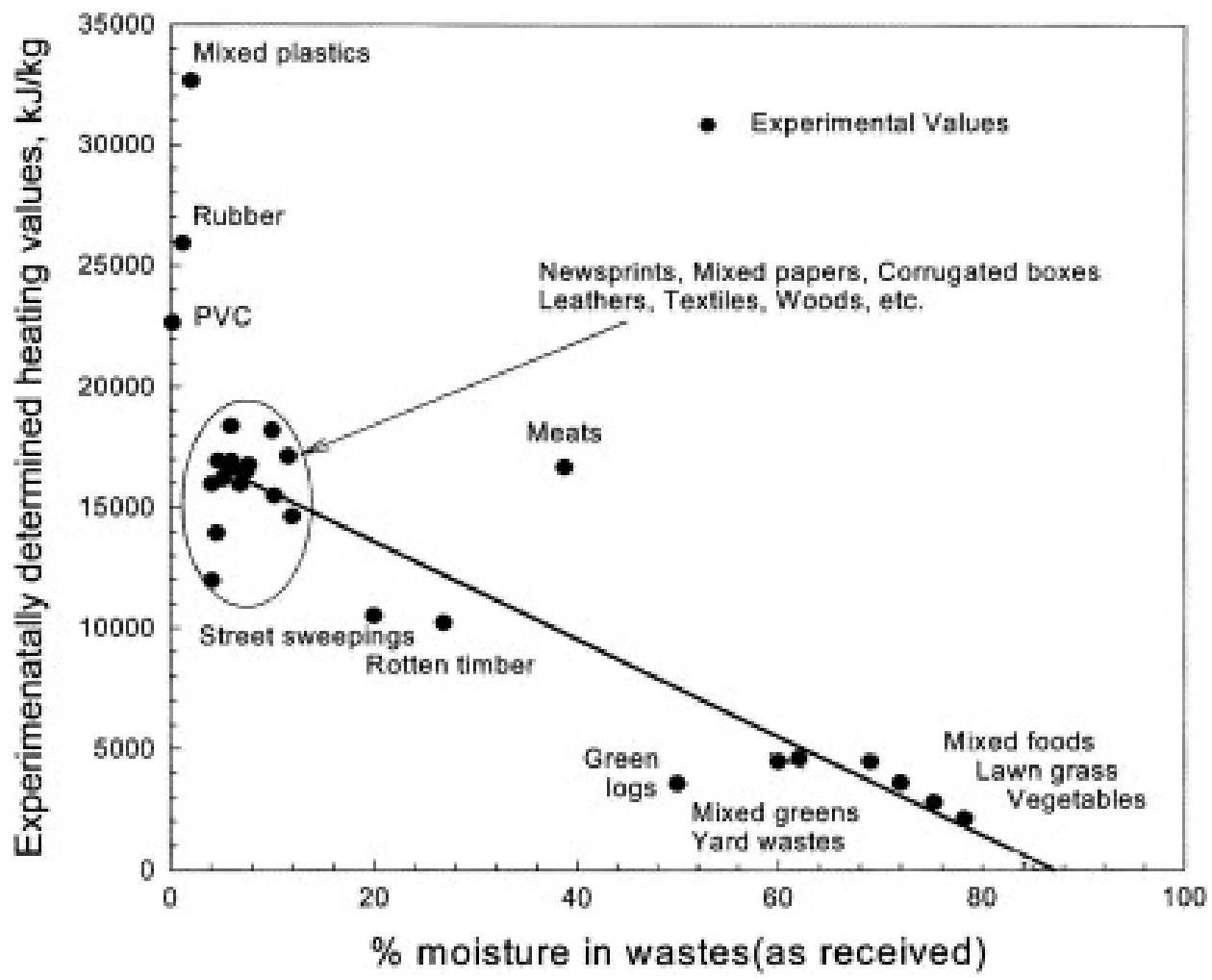

Figure 3.3. Variation of Heating Values of Solid Waste Components as a Function of Moisture Content (Themelis et al. 2002)

The chemical composition of MSW is also important because it contains many substances that can produce gas contaminants that create problems for downstream processes using catalysts including steam reforming and water-gas shift, and liquid fuels syntheses. A summary of compiled elemental analysis for bulk MSW (Phyllis 2008) is given in

Table 3.1. This data provides a gross estimation of the concentrations of selected elements that can be found in MSW. Of particular note are S, Cl, F, As and P, which can be present as gaseous constituents in the product gas from a gasifier and are known catalyst poisons for liquid fuels synthesis processes.

Other elements of note are $\mathrm{Cd}$ and $\mathrm{Hg}$, which are volatile metals that may be difficult remove and are also potential catalyst poisons. The data presented in

Table 3.1 has limited applicability to specific sites. It may be used as a first approximation for raw MSW, but cannot reflect streams where fractions have been separated out as a gasification feedstock, such as in the production of RDF. Figure 3.4 shows a comparison of the general elemental composition of MSW with RDF, common biomass fuels, and coal (Phyllis 2008). 
Table 3.1. Elemental Composition of Bulk MSW

\begin{tabular}{|c|c|c|c|c|c|}
\hline Component & Metric & Mean & Min & Max & $\begin{array}{c}\text { \# of } \\
\text { References }\end{array}$ \\
\hline Water & wt\% wet & 14.6 & 2.9 & 38.7 & 26 \\
\hline Volatiles & wt $\%$ daf & 88.7 & 74.6 & 99.4 & 22 \\
\hline Ash & wt $\%$ dry & 17 & 4.4 & 44.2 & 33 \\
\hline $\mathrm{HHV}$ & $\mathrm{kJ} / \mathrm{kg}$ daf & 24597 & 13130 & 44029 & 35 \\
\hline LHV & $\mathrm{kJ} / \mathrm{kg}$ daf & 22915 & 12126 & 10986 & 33 \\
\hline $\mathrm{C}$ & wt $\%$ daf & 54.8 & 33.9 & 84.8 & 34 \\
\hline $\mathrm{H}$ & wt $\%$ daf & 8.12 & 1.72 & 15.16 & 34 \\
\hline $\mathrm{O}$ & wt $\%$ daf & 34 & 15.8 & 43.7 & 33 \\
\hline $\mathrm{N}$ & wt $\%$ daf & 0.94 & 0.12 & 2.37 & 34 \\
\hline $\mathrm{S}$ & wt $\%$ daf & 0.4 & 0.006 & 1.4 & 30 \\
\hline $\mathrm{Cl}$ & wt $\%$ daf & 0.716 & 0 & 1.558 & 25 \\
\hline $\mathrm{F}$ & wt $\%$ daf & 0.014 & 0 & 0.043 & 3 \\
\hline $\mathrm{Br}$ & wt $\%$ daf & 0.001 & 0 & 0.002 & 3 \\
\hline $\mathrm{Al}$ & $\mathrm{mg} / \mathrm{kg}$ dry & 1600 & 1600 & 1600 & 1 \\
\hline As & $\mathrm{mg} / \mathrm{kg}$ dry & 6.9 & 1.5 & 15 & 5 \\
\hline $\mathrm{Cd}$ & $\mathrm{mg} / \mathrm{kg}$ dry & 13.6 & 1 & 35 & 5 \\
\hline Co & $\mathrm{mg} / \mathrm{kg}$ dry & 46.7 & 0.1 & 130 & 5 \\
\hline $\mathrm{Cr}$ & $\mathrm{mg} / \mathrm{kg}$ dry & 94.6 & 8 & 240 & 5 \\
\hline $\mathrm{Cu}$ & $\mathrm{mg} / \mathrm{kg}$ dry & 325 & 35 & 750 & 5 \\
\hline $\mathrm{Fe}$ & $\mathrm{mg} / \mathrm{kg}$ dry & 752.7 & 490 & 1000 & 3 \\
\hline $\mathrm{Hg}$ & $\mathrm{mg} / \mathrm{kg}$ dry & 0.6 & 0.1 & 2 & 5 \\
\hline $\mathrm{Mg}$ & $\mathrm{mg} / \mathrm{kg}$ dry & 120 & 100 & 130 & 3 \\
\hline $\mathrm{Mn}$ & $\mathrm{mg} / \mathrm{kg}$ dry & 156.8 & 10 & 290 & 4 \\
\hline Mo & $\mathrm{mg} / \mathrm{kg}$ dry & 29 & 2 & 50 & 3 \\
\hline $\mathrm{Ni}$ & $\mathrm{mg} / \mathrm{kg}$ dry & 59.6 & 1 & 150 & 5 \\
\hline$P$ & $\mathrm{mg} / \mathrm{kg}$ dry & 546.7 & 40 & 850 & 3 \\
\hline $\mathrm{Pb}$ & $\mathrm{mg} / \mathrm{kg}$ dry & 226 & 50 & 350 & 5 \\
\hline $\mathrm{Sb}$ & $\mathrm{mg} / \mathrm{kg}$ dry & 13.3 & 10 & 20 & 3 \\
\hline Sn & $\mathrm{mg} / \mathrm{kg}$ dry & 0.1 & 0.1 & 0.2 & 2 \\
\hline $\mathrm{Ti}$ & $\mathrm{mg} / \mathrm{kg}$ dry & 145 & 100 & 190 & 2 \\
\hline V & $\mathrm{mg} / \mathrm{kg}$ dry & 37.3 & 4 & 75 & 4 \\
\hline $\mathrm{Zn}$ & $\mathrm{mg} / \mathrm{kg}$ dry & 306.3 & 85 & 500 & 4 \\
\hline
\end{tabular}

$1 \mathrm{~kJ} / \mathrm{kg}=0.43021 \mathrm{Btu} / \mathrm{lb}$

$1 \mathrm{mg} / \mathrm{kg}=1 \mathrm{ppm}$ 


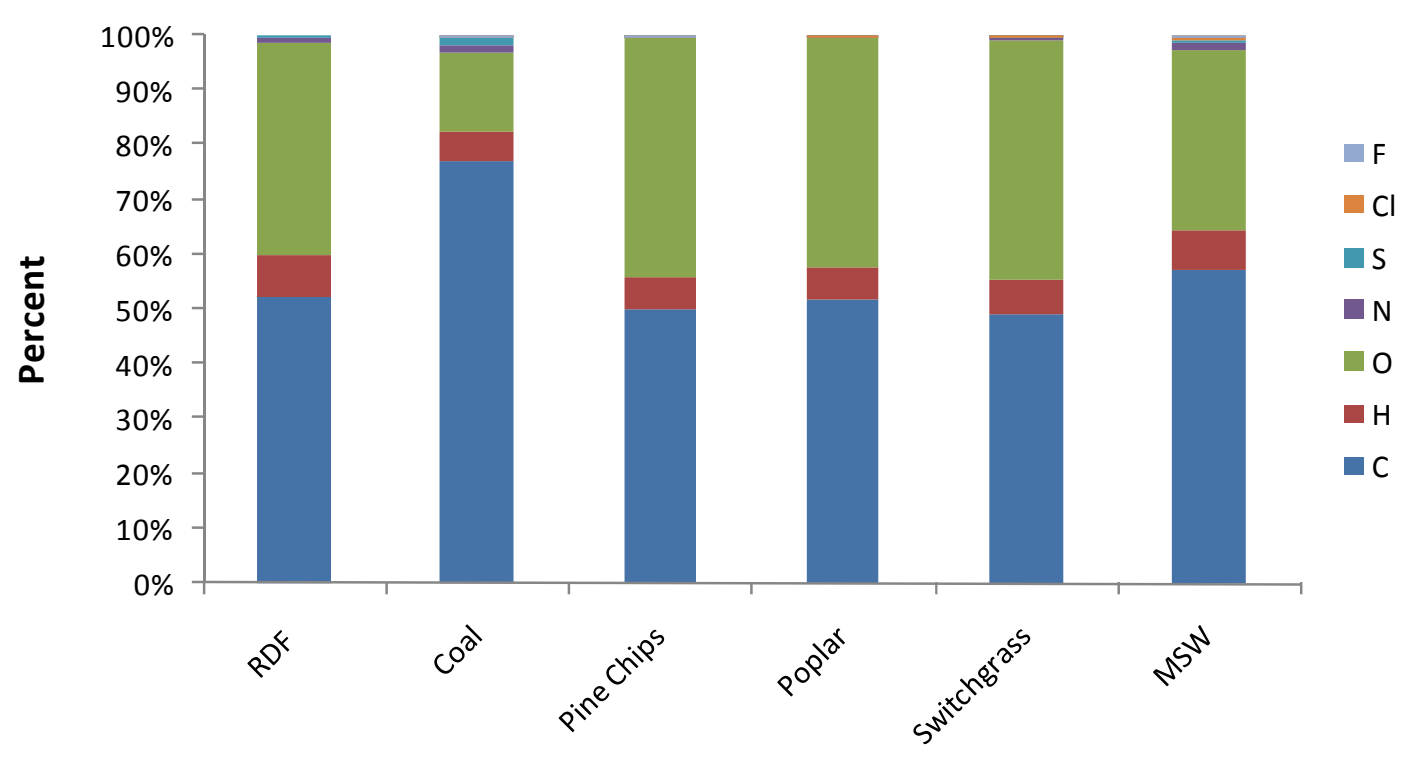

Fuel

Figure 3.4. Elemental Comparison of RDF and MSW with Conventional Gasifier Fuels

\subsection{Economic Issues Affecting MSW Suitability as a Feedstock}

Another important issue affecting the suitability of MSW as a feedstock for liquid fuels synthesis is its cost and how that cost affects the necessary plant scale needed to economically produce the liquid fuels. For example, a 2008 study showed that a conventional biomass (poplar wood) to mixed alcohol synthesis facility becomes economically feasible at a scale of 2,000 dry tonnes ( 2200 short tons) per day (Stiles et al. 2008). Using the HHV of biomass feedstock as the basis for estimating the product output from a liquid fuels synthesis facility, a rough estimate can be made regarding the amount of MSW or RDF feed that would be required for a similarly sized facility based on product output. Using the HHVs (dry basis) in Figure 3.2, a 2,200 dry short ton per day biomass fed facility would require approximately 2,400 dry short tons per day of dry MSW or 2,300 dry short tons per day of dry RDF to supply the same quantity of stored energy to the gasifier. Using the water content values in Figure 3.1, the as arrived MSW and RDF feedstock requirements would be approximately 3,300 and 2,755 short tons per day, respectively. MSW required to supply 2,755 short tons per day of RDF would range from 3,200 to 3,400 short tons per day based on previous discussions on MSW to RDF conversion.

The actual plant scale for an MSW fed process may not be the same as that for a biomass fed process because the cost of the feedstock must be taken into account. The biomass study discussed above assumed a $\$ 48.46 /$ dry tonne ( $\$ 44 /$ dry short ton) cost and accounts for a significant fraction of the total product cost. If the biomass cost could be significantly reduced then the reduced operating costs could off-set the diseconomies of scale of a smaller plant so that a smaller scale plant could still produce a product with the same selling price.

Biomass conversion facilities using traditional forms of biomass feedstocks, such as wood chips, must pay a market price based on the value of the biomass. This value considers the cost to produce and/or collect the biomass and its open market value as feedstock. Consequently, a plant operator has limited flexibility in the price paid for biomass. MSW disposal and conversion facilities, however, charge 
a tipping fee for MSW based on the cost to dispose of the waste. The tipping fees charged for MSW are regulated, at least in part by local governing agencies such as cities or counties, mostly because many local municipalities also own their own landfills. As such, they may allow a reasonable profit after paying for the necessities; sorting and recovery of recyclables (if performed), incineration of a portion of the recovered materials (if performed), any unrecovered material, incinerated ash disposal, and future site remediation. Unless a flow control is in place, which would require full support of the local municipality, this scenario would promote reasonable tipping fees based on the recovery/disposal pathway costs by surrounding landfill management entities.

Tipping fees vary widely across the country. A tipping fee survey by (Repa 2005) showed that regional average tipping fees in 2004 ranged from a low of $\$ 24.06$ per ton in the south to $\$ 70.06$ per ton in the Northeast. Tipping fees within a state can also vary widely. For example, in 2000, county charges within Florida ranged from $\$ 23.00$ per ton in Manetee County to $\$ 92$ per ton in Monroe County (Florida Department of Environmental Protection 1999). Lower tipping fees are thought to reflect continued use of older, established landfills built prior to Resource Conservation and Recovery Act (RCRA), Subtitle D (40 CFR Part 257, 40 CFR Part 258)regulations that were put into effect October 9, 1993. RCRA regulations are also thought to render small landfills ( $<500$ short tons per day) prohibitively expensive to build and operate (EPA-530-R-99-016 1999, EPA-530-R-99-013 1999).

Understanding regional flows, with such a wide range in tipping fees structure, is not straightforward. This is because state and local governments began implementing flow controls, in the late 1970s, to spur the development of new MSW capacity. Flow controls are defined by the EPA as "legal authorities used by State and local governments to designate where MSW must be taken for processing, treatment or disposal" (EPA-530-R-95-008 1995). A direct effect of such flow controls is assurance that designated facilities receive a guaranteed amount of MSW (and/or recyclables in the case of materials recovery facilities); hence a source of revenue to meet capital and operating costs. Flow controls are highly controversial and often fought, legally, on the basis that they limit free commerce (especially interstate).

In addition to local flow controls, competition for MSW may be found in tipping fees charged for local waste versus waste brought in from outside the area of operation. For example, 1992 tipping fees for local waste were reported to be $\$ 55$ and $\$ 63.50$ in Broward County, Florida and Montgomery County, Pennsylvania, respectively. Tipping fees for outside waste, in these counties, was reported at $\$ 42$ and $\$ 41$ per short ton. Both localities were also reported to use flow controls to guarantee local waste (EPA-530-R-95-008 1995).

Finally, tipping fees are affected by the manner in which the MSW is disposed. For example, the tipping fees for MSW that was disposed in landfills averaged about \$34.29/ton nationwide (in 2004) while the tipping fees for MSW that was incinerated averaged about $\$ 61.64$ nationwide (Repa 2005). This difference can be attributed to the increased cost of incineration as a means for disposal. By adding a processing cost to the tipping fee for MSW disposal, it may be possible to reduce the scale required for converting MSW to liquid fuels to a smaller size that better fits the MSW disposal site capacity. A more detailed economic analysis would be required to determine how much processing cost would need to be added to a tipping fee for various plant sizes, along with an assessment of the willingness of the public to accept these additional charges. 


\subsection{Availability and Distribution of MSW}

MSW has an immediate advantage over biomass as a feedstock in that it is already collected at sites around the country and disposed in landfills. However, there is considerable variability in the annual capacity of these sites and, as was previously discussed, there is probably a minimum capacity below which the economics are not favorable for converting MSW into liquid fuels.

MSW generation rates are often given per capita to understand distribution, and are based on data compiled by the EPA, further supported by the U.S Census Bureau. Thus, a map showing population density would be indicative of the distribution of the nation's MSW stream. Figure 4.1 is a population density map generated using U.S. Geological Survey and U.S. Census Bureau data (National Atlas of the United States). Note that the Mid-West and Rocky Mountain regions show the least population density. Interestingly, several states in this region allow back-yard and mass burning of MSW. In any case, supplying sufficient feedstock to a thermochemical conversion plant appears to be most likely in regions on the East and West coasts.

Actual availability of MSW, within a given region, is dependent upon several, dynamic factors. The implementation of the RCRA Subtitle D regulations in 1993 spurred a movement from small, distributed landfills to larger landfills equipped to contain contamination and vent combustible gases. This trend toward larger landfills is shown in Figure 4.2 (Franklin Associates 2008). At the same time landfill site management shifted towards large companies with landfill site management expertise to implement the RCRA regulations. For example, in 1992, there were 5386 landfill sites reported by the EPA in the United States, of which 348 sites were owned or operated by the 13 largest waste management companies that operated landfill sites (approximately 6\% of all active sites) (EPA-530-R-95-008 1995). By 2008, the EPA reported only 1754 active landfill sites. An Internet search of the major waste management companies indentified 574 landfill sites owned or operated by the 13 largest waste management companies that operated landfills (approximately $33 \%$ of all active sites). The trend towards fewer larger landfill sites accompanied by the trend towards more sites operated by waste management companies, who could be important collaborators, should improve the potential for finding opportunities for siting MSW liquid fuels synthesis plants.

A MSW mass range of 3,200-3,400 short tons per day (described above in Section 3.2) was determined to be equivalent to the economically-viable 2,000 tonne per day wood gasifier, based on relative moisture contents and heating values (Figures 3.1 and 3.2). Landfill disposal weights (or volumes ${ }^{1}$ ) were collected from 44 states $^{2,3}$. This data was inspected to evaluate the number of landfills, nation-wide, meeting a 3,300 short tons per day criteria. The results are shown in Figure 4.33

. These preliminary results indicate 47 potential landfill sites receiving 3,300, or more, short tons per day.

\footnotetext{
${ }^{1}$ MSW density is highly dependent upon the level of compaction. An average MSW density of 0.25 tons per cubic yard was assumed for this report.

${ }^{2}$ Disposal mass data was collected by searching publicly available internet databases and contacting landfill sites via telephone.

${ }^{3}$ Landfill site-specific data was not available for Alaska, Kansas, Montana, Rhode Island, Wyoming, and Florida. It is likely that 3 counties in Alabama, 1 county in Kansas, 1 county in Rhode Island and 6 counties in Florida could support facilities processing 2755 or more short tons per day.
} 
Interestingly, these 47 landfills take in an average of 5,700 short tons per day, each. For perspective, assume that MSW gasification can support a liquid fuels (e.g. ethanol) synthesis operation at a rate of approximately 48.6 gallons per short ton (roughly $2 / 3$ the potential 72.6 gallons of ethanol per ton from wood gasification, based on relative heating values). If 47 plants processed 5,700 short tons per day, and generated 48.6 gallons of ethanol per short ton, the expected output of the combined plants would be $310,000 \mathrm{bbl}$ per day, or $113 \mathrm{MM}$ bbl per year. The EIA reported a total liquid fuels consumption, in the U.S., of approximately 40 quadrillion Btu in 2006 and (as shown in Figure 1.1) a transportation sector demand of 28 quadrillion Btu in 2008. Assuming a HHV of 84,000 Btu per gallon of ethanol, 47 plants could supply 0.4 quadrillion Btu in 2006 ( $1 \%$ of total liquid fuels consumption) or $1.4 \%$ of transportation sector energy demand. 


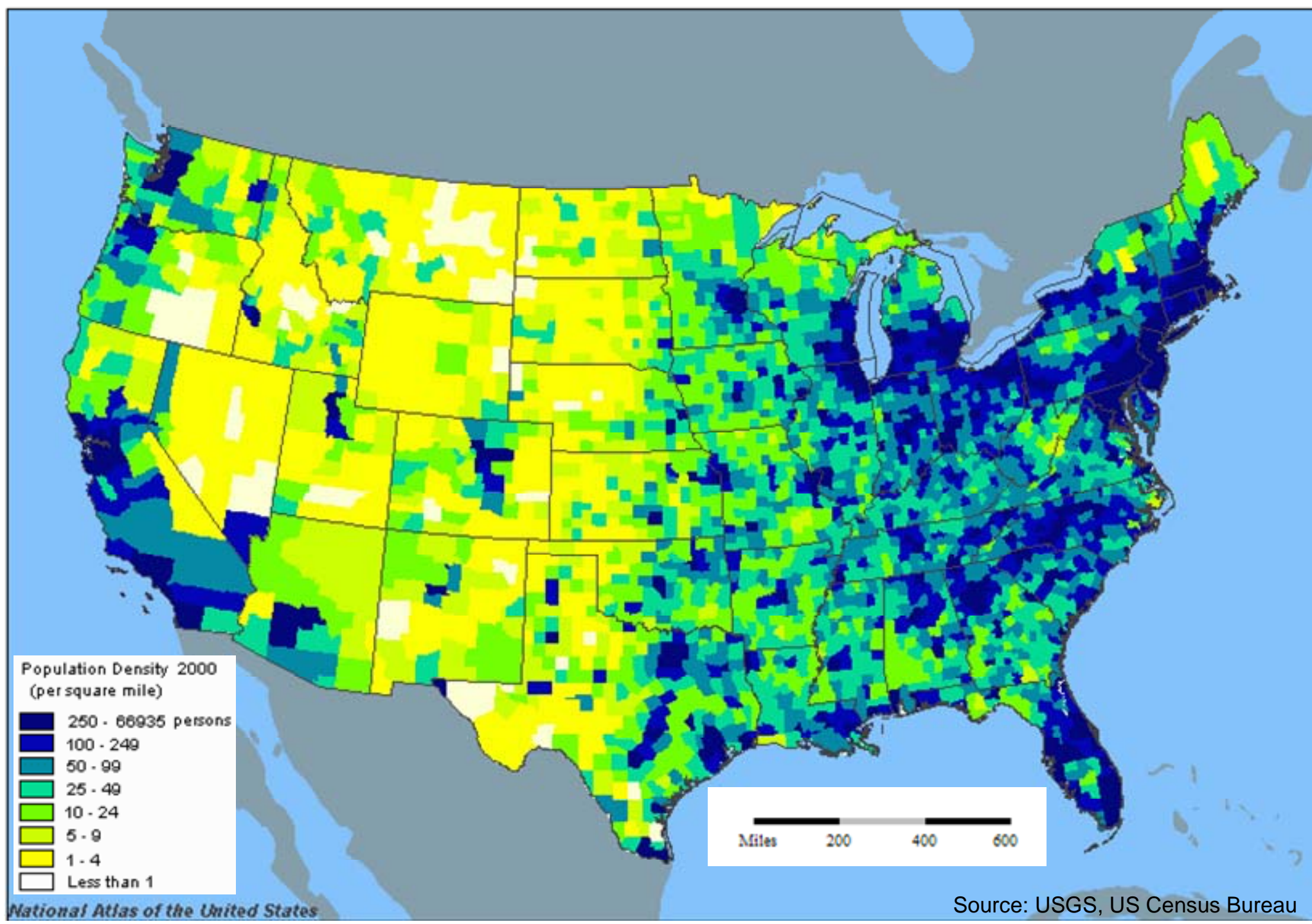

Figure 4.1. United States Population Density (Interior 2008) 


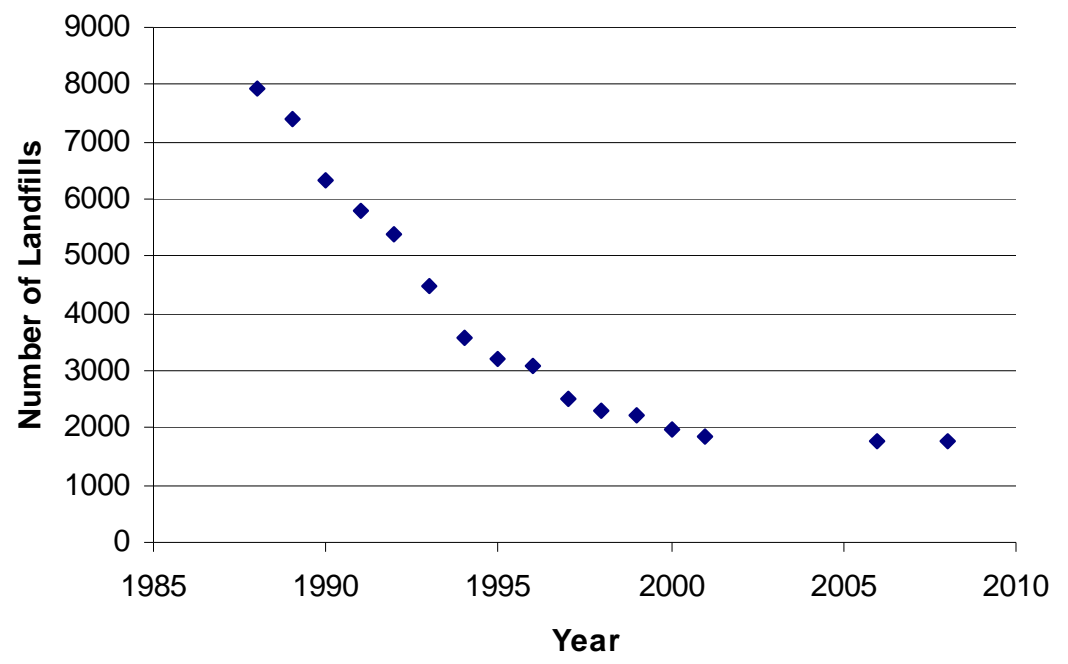

Figure 4.2. Number of Landfills, Nation-Wide, Since 1988

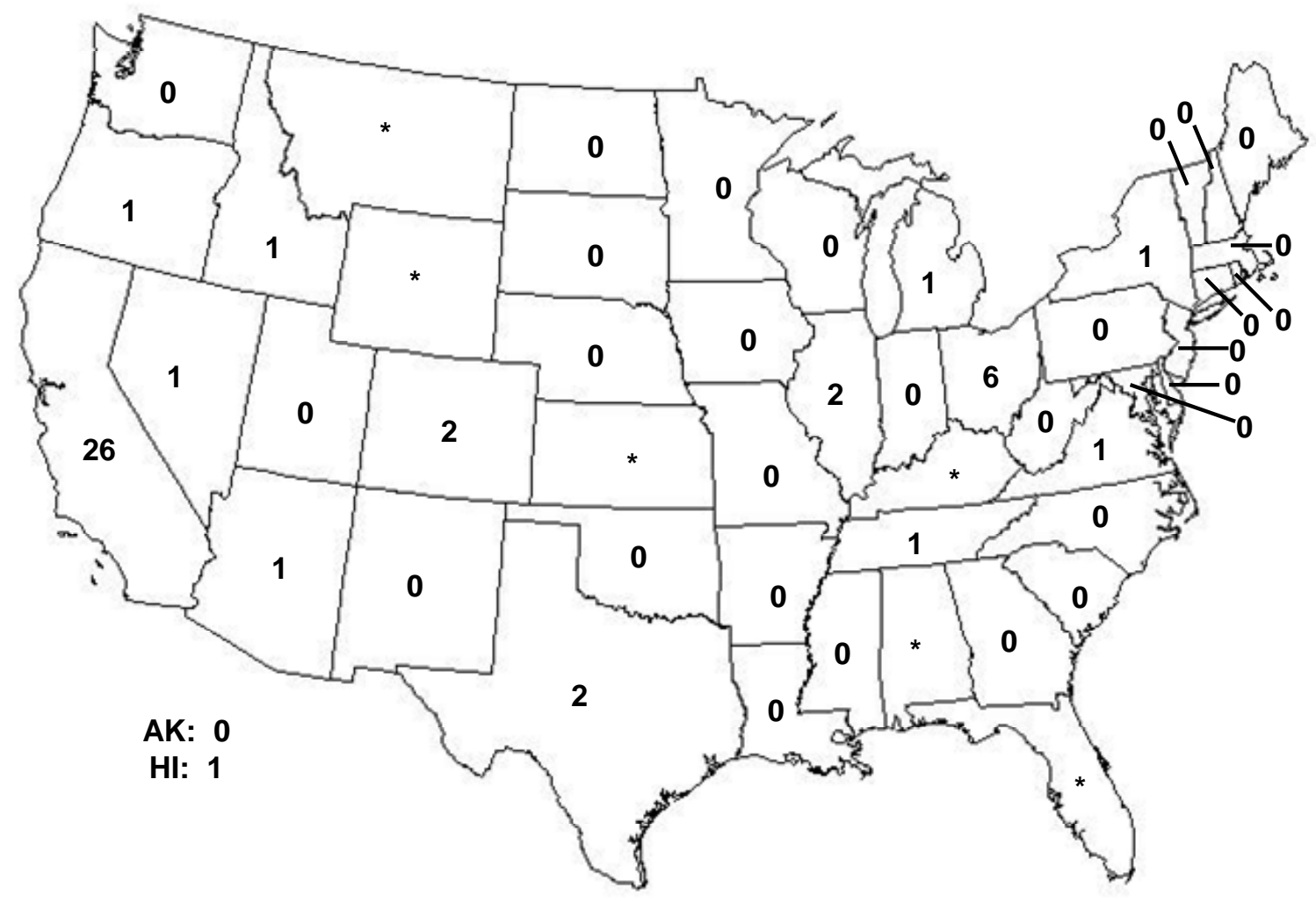

Figure 4.3. U.S. Landfills Receiving $\geq 3300$ Short Tons per Day

The daily throughput of landfills, as collected from the 44 states in which site-specific data was available, is shown in Figure 4.4. Although $90 \%$ of the nation's landfills process 1750 short tons per day or less, almost $30 \%$ of MSW goes to landfills processing 3,300 short tons per day or more. An additional $30 \%$ of the nation's MSW enters landfills handling between 1250 and 3300 short tons per day. Thus, an economically viable gasification technology, operating at these smaller scales, could be important. 


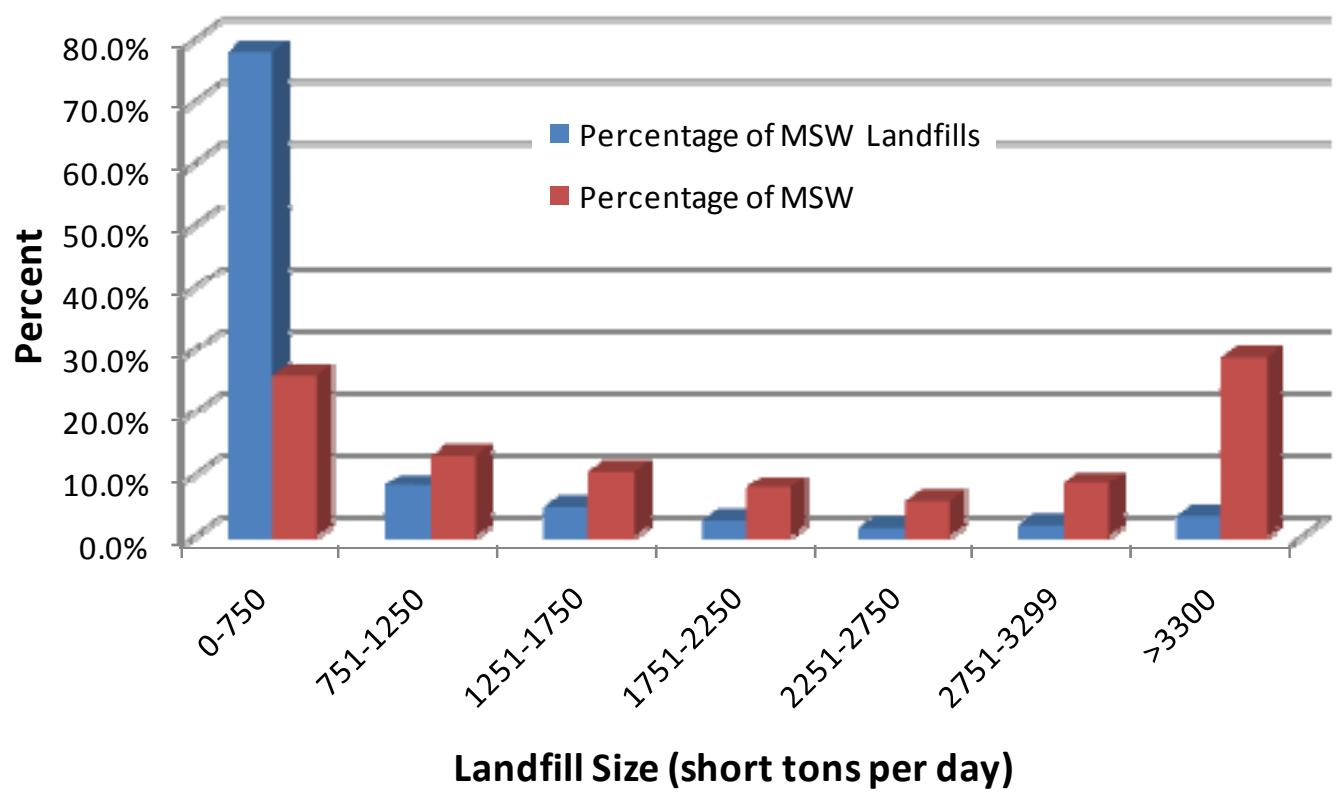

Figure 4.4. Throughput Distribution Processed by the Nation's Active Municipal Solid Waste Landfills

It should be noted that the data collected from local government departments on individual landfills (or counties) differed greatly from the numbers reported by larger entities, such as the EPA. The total MSW entering MSW landfills, as reported by local governments, was $341 \mathrm{MM}$ short tons. This is more than 35\% greater than the $251 \mathrm{MM}$ short tons produced in the US, based on EPA estimates. Furthermore, the EPA estimates that a significant portion of the produced MSW is recycled or composed, thus not entering landfill sites. The higher estimate based on local governments and local landfills may be due to many factors including non-MSW ( $C \&$ D debris, biosolids, and agricultural wastes) material entering landfills, the use of estimation at landfill sites without scales, and the uncertainty of product lifetimes assumed in the material balance method used by EPA. Other factors adding to this discrepancy involve uncertainties regarding diversions that occur after material has entered a given landfill. For example, a landfill site may report MSW entering the landfill gate that is later sorted for recycle, or used in an incinerator or composting operation instead of being disposed in a landfill. The difference between estimated MSW generation and state reporting has also been documented in other 2004 and 2006 studies (Simmons 2006, 2006a). This further justifies the necessity for careful data evaluation.

It should also be noted that large MSW landfill sites are already generally more technologically advanced. This advancement was likely set in motion by RCRA Subtitle D, which limits landfill gas concentrations of methane in occupied structures onsite and soil atmosphere at the property line of the landfill site to $1.25 \%$ and $5 \%$, respectively. Preliminary investigation into the potential landfill sites revealed that $58 \%$ already have landfill gas (LFG) recovery operations in place. Other sites incinerate MSW to produce electric power. This means that a MSW gasification strategy may come to be in direct competition with these existing operations. On the other hand, LFG recovery and gasification systems could be complementary, with the methane used to raise steam for the gasification plant, ensuring that more of the MSW goes to liquid fuels. Such a cooperative venture would be temporary, unless carefully strategized to maintain sufficient LFG generation. 


\subsection{Current State of Gasification Technology}

There are more than 140 gasification plants currently in operation worldwide comprising more than 420 gasifiers. Most of these gasifiers use coal feedstocks. Worldwide gasification capacity is expected to increase $80 \%$ by 2015 with most of that increase occurring in China (Gasification Technologies Council 2008).

Biomass gasification and incineration are proven commercial technologies worldwide for both conventional biomass and MSW. However, these applications are generally limited to firing boilers for process heat and electricity generation and, in a few cases for gasification supplying a gaseous fuel to a diesel generator system. The process scale for these applications is case specific ranging anywhere from a few to several hundred dry tons/day with applications for power generation generally in the larger sizes. There have been some demonstration-scale efforts with conventional biomass feedstocks to provide gas for a gas turbine, but inadequate reduction of tar levels in the product gas has proven to be a technical barrier at this time (Cobb 2007). Biomass gasification for liquid fuels synthesis using either conventional biomass feedstocks or MSW has not been developed at this time. This is mainly due to economic issues involving maximum practical scale of biomass conversion plants with respect to resource availability and the minimum scale required to produce liquid fuels using synthesis gas for various liquid products. Closely tied to these economic issues are technical issues regarding efficient and cost effective gas cleanup technologies to remove tars and trace gas contaminants such as $\mathrm{H}_{2} \mathrm{~S}$ as well as efficient catalystic processes to convert synthesis gas into liquid products.

There is considerable variety in the specific designs of gasifiers. Many of these variations are derived from specific application needs regarding process scale, gas quality, feedstock introduction, and ash management. However, from a flow dynamics perspective, there are four general gasifier types-fixed bed, fluidized bed, entrained flow, and plasma reactors. Each general gasifier type has unique benefits and drawbacks depending not only on the desired feedstock but the end product as well.

\subsection{Fixed Bed Gasifiers}

The fixed bed gasifiers are relatively simple in design with biomass added to the top of the gasifier vessel and ash and unreacted char removed from the bottom. They are called fixed bed because the biomass does not move freely in the reactor. Instead the biomass moves slowly downward through a fixed zone supported by a grate at the bottom of the gasifier. Fixed bed gasifiers are relatively small in size and are directly heated using air, although purified oxygen could also be used.

There are two main fixed bed gasifier designs. An up-draft gasifier is a counter flow design in which biomass moves downward through the gasifier while air is introduced into the bottom of the gasifer and the reacted gases exit the top. In this configuration, biomass entering the top is slowly heated as it moves down through the bed giving off moisture, pyrolysis gases (hydrogen, carbon monoxide, carbon dioxide, and light hydrocarbon gases), and vaporized pyrolysis liquids called tars that are carried upward with the gas flow leaving with the product gas at concentrations typically ranging from $1.2 \times 10^{-3}$ to $5.9 \times 10^{-3}$ lbs/scf (NREL/TP-570-25357). Gases exiting the updraft gasifer are at a relatively modest temperature of approximately $930^{\circ} \mathrm{F}$ (Ciferno and Marano 2002). Char produced from slow pyrolysis of the biomass continues downward to a grate where air is introduced combusting the char. Heat from this combustion process drives the endothermic drying and pyrolysis reactions. Ash and unreacted char drop through the grate and are removed from the gasifier. A simplified illustration of an up-draft gasifier is given in Figure 5.1. 


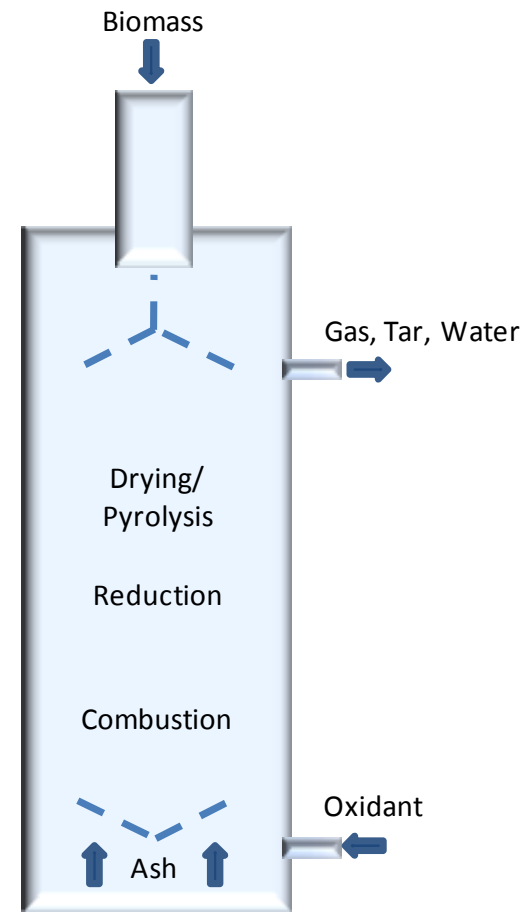

Figure 5.1. Simplified Schematic of an Up-Draft, Fixed-Bed Gasifier

In a down-draft gasifier design, biomass also is added at the top of the reactor and works its way downward, slowly drying and pyrolyzing. The moisture, pyrolysis gases, and tars produced as the biomass slowly pyrolyzes pass downward to the bottom of the gasifer vessel passing through a zone where air is introduced to the gasifier. The air combusts the pyrolysis gases, tars, and a portion of the char producing a high temperature zone (approximately $1800^{\circ} \mathrm{F}$ ), where steam and $\mathrm{CO}_{2}$ in the gas stream can react with the remaining char producing additional hydrogen and carbon monoxide (Cirferno and Marano 2002). The gas stream leaves the gasifier just above a grate at the bottom of the vessel at approximately $1475^{\circ} \mathrm{F}$, while ash and unreacted char fall through the grate and are removed. Tars in the product gas typically range from $5.9 \times 10^{-6}$ to $7.1 \times 10^{-5} \mathrm{lbs} / \mathrm{scf}$ (Milne et al. 1998). A simplified illustration of a down-draft gasifier is given in Figure 5.2.

There are hybrid fixed bed gasifier designs that possess elements of updraft and downdraft gasifiers. Baffles and alternative points of air introduction create combustion zones that may not be fully mixed with all gases and tars evolved in cooler parts of the gasifier as would occur in a downdraft gasifier. However, those gases and and tars do experience much higher temperatures than are experienced in an updraft gasifer, providing opportunities for tar cracking.

Both fixed bed gasifiers designs are simple, low-cost processes but they are also limited in capacity because of the relatively long biomass residence times and practical limits on vessel size. Up-draft gasifiers can handle feedstocks with relatively high moisture content and high ash content making them suitable for MSW with minimal processing. Their main disadvantage besides size is the high tar content in the product gas reaching as high as $10 \%$ to $20 \%$ by weight (Ciferno and Marano 2002). Down-draft gasifiers are very efficient in converting pyrolysis tars to gas producing a gas that is essentially tar-free, at least in smaller-scale applications. Both gasifiers can handle fairly coarse material although the constriction in the bottom of a down-draft gasifier is more limited in this aspect. 


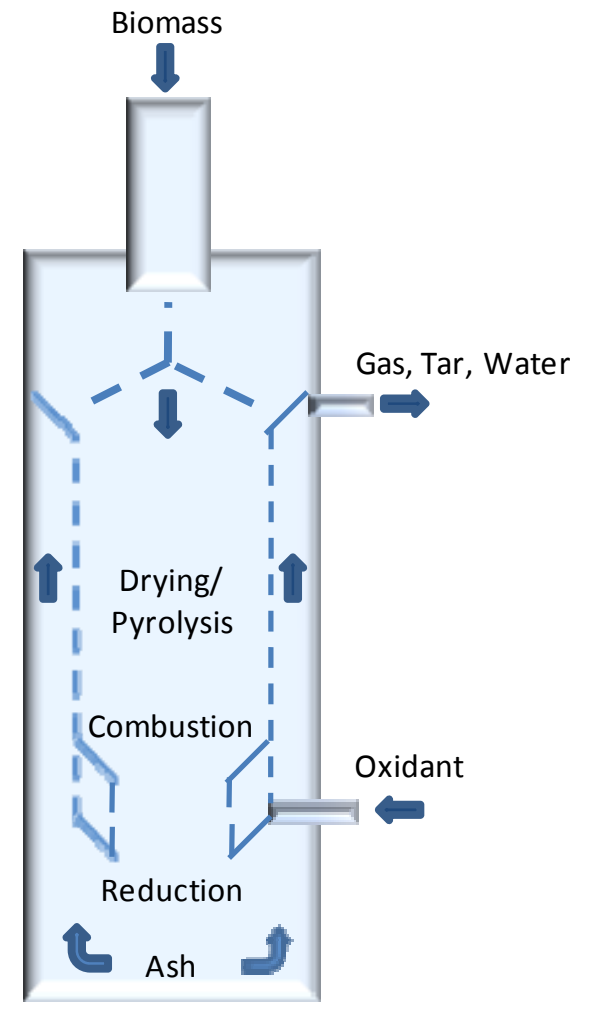

Figure 5.2. Simplified Schematic of a Down-Draft, Fixed-Bed Gasifier

\subsection{Fluidized Bed Gasifiers}

Fluidized bed gasifiers are characterized by the use of a heated solid medium, such as sand made to bubble (or "boil") by introducing the gas stream below the sand bed at sufficient velocity to barely lift (fluidize) the sand so that the sand particles are free to move throughout the sand bed. Biomass is introduced into the fluidized bed either from the top or from the side and mixed with the hot sand causing rapid pyrolysis to produce mostly gas and a small quantity of tar and char. A direct fired fluidized bed is heated by introducing air or purified oxygen into the bottom of the bed as all or part of the fluidizing gas (steam is also added in some applications). The oxygen in the fluidizing gas combusts a portion of the pyrolysis gases, char and tar then passes out the top of the gasifier vessel. Char is ground up by the motion of the sand to small char and ash particles that are carried out of the gasifier where they must be removed by cyclones. An indirectly heated fluidized bed gasifier withdraws a portion of the fluidized bed contents including the char in the bed and transfers it to a second fluidized bed where air is introduced into the bottom of the second vessel to combust the char thereby heating the sand to a high temperature. The hot sand is then transferred back to the gasifier where the hot sand is used to heat the biomass. Only steam is introduced to the bottom of the gasifer in this configuration to fluidize the bed. This type of configuration is often called a circulating fluidized bed because the solids are withdrawn and reintroduced to the gasifer. Fluidized bed gasifiers typically operate at moderately high temperatures $\left(1300^{\circ} \mathrm{F}-1750^{\circ} \mathrm{F}\right)$, utilize a solid fuel stream, and have residence times ranging from one second to a minute. Simplified illustrations of a fluidized bed gasifier and a circulating fluidized bed gasifier are given in Figures 5.3 and 5.4, respectively. 


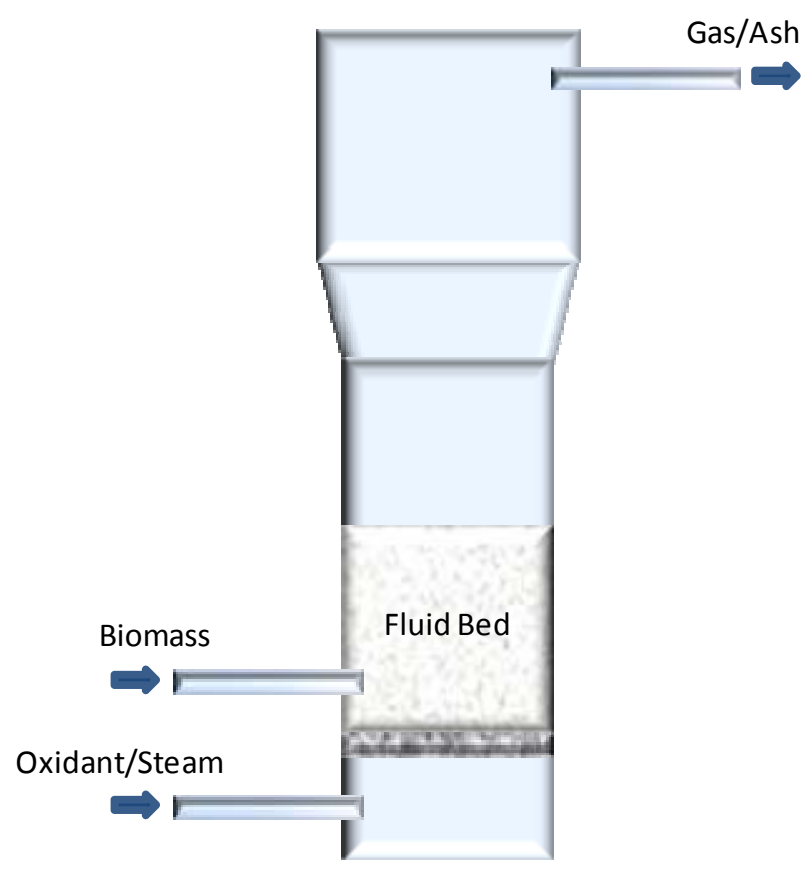

Figure 5.3. Simplified Schematic of a Fluidized Bed Gasifier

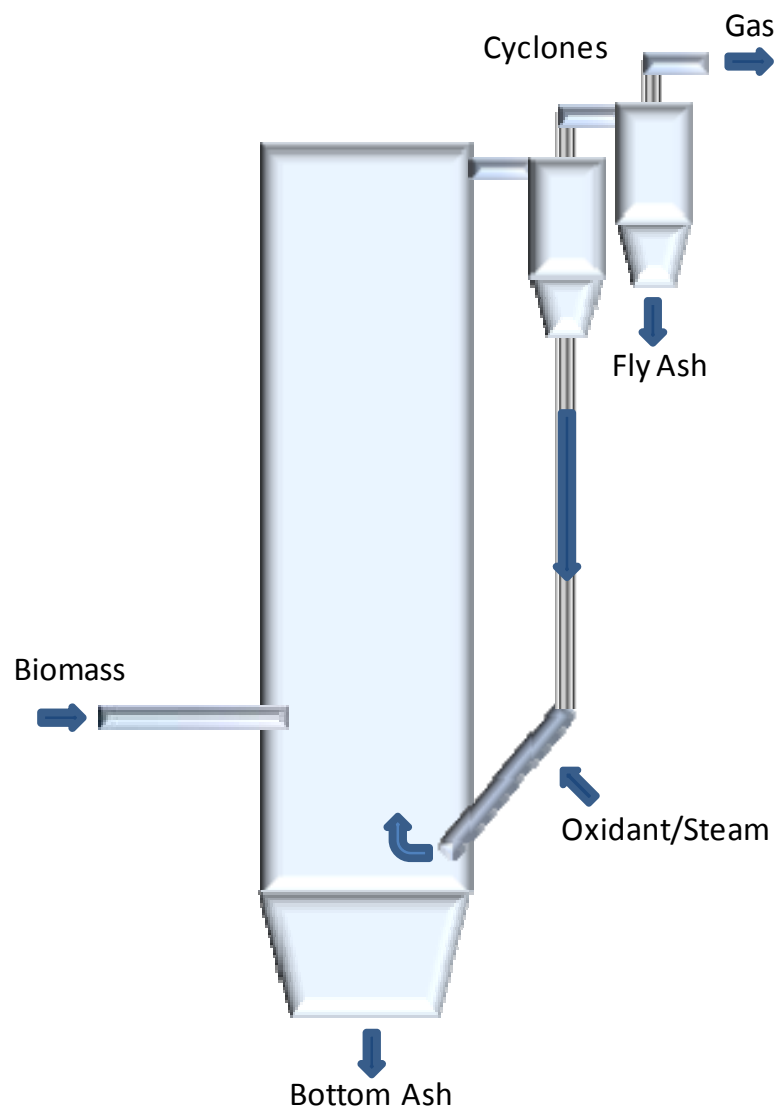

Figure 5.4. Simplified Schematic of a Circulating, Fluidized Bed Gasifier 
Fluidized bed gasifiers can be scaled to relatively high capacities because of the much shorter biomass solids residence times in the gasifier. However, there are more limitations on the physical properties of the feedstock because the solids must be fluidizable or they must be removed from the bottom of the vessel. In the case of MSW, this would most likely require separation of large heavy objects (metals and other heavy inorganic solids) and size reduction and screening to achieve particles with similar aerodynamic properties with respect to fluidization. RDF would be particularly suitable as a feedstock. Product gas from fluidized bed gasifiers also contains a small quantity of tars typically ranging from $5.9 \times 10^{-5}-8.9 \times 10^{-4} \mathrm{lbs} / \mathrm{scf}$ (Milne et al. 1998). These tars must be reduced to much lower levels for synthesis gas applications, either by separation or by conversion into gas.

\subsection{Entrained Flow Gasifiers}

Entrained flow gasifiers (also sometimes called circulating bed gasifiers) are similar to fluidized bed gasifiers except that the gases introduced into the bottom of the gasifier vessel are at a much higher velocity causing the fluidized medium and biomass to become entrained and carried out the top of the gasifier. Solids residence times in the gasifier range for 1-10 seconds and the temperatures are higher $\left(1650^{\circ} \mathrm{F}-2550^{\circ} \mathrm{F}\right)$. Solids are removed from the product gas and either returned to the gasifier or sent to a separate combustor where the char is combusted. An entrained bed gasifier may be directly fired with air or oxygen or indirectly heated (using the separate combustor to heat the sand). The advantages and disadvantages of entrained flow gasifiers are similar to those for fluidized bed gasifiers except the throughputs can be greater, but the solids properties are usually more stringent. The high velocities of the entrained solids may also accelerate equipment erosion, compared to a fluidized bed gasifier. Figure 5.5 is a simplified illustration of an entrained flow gasifier.

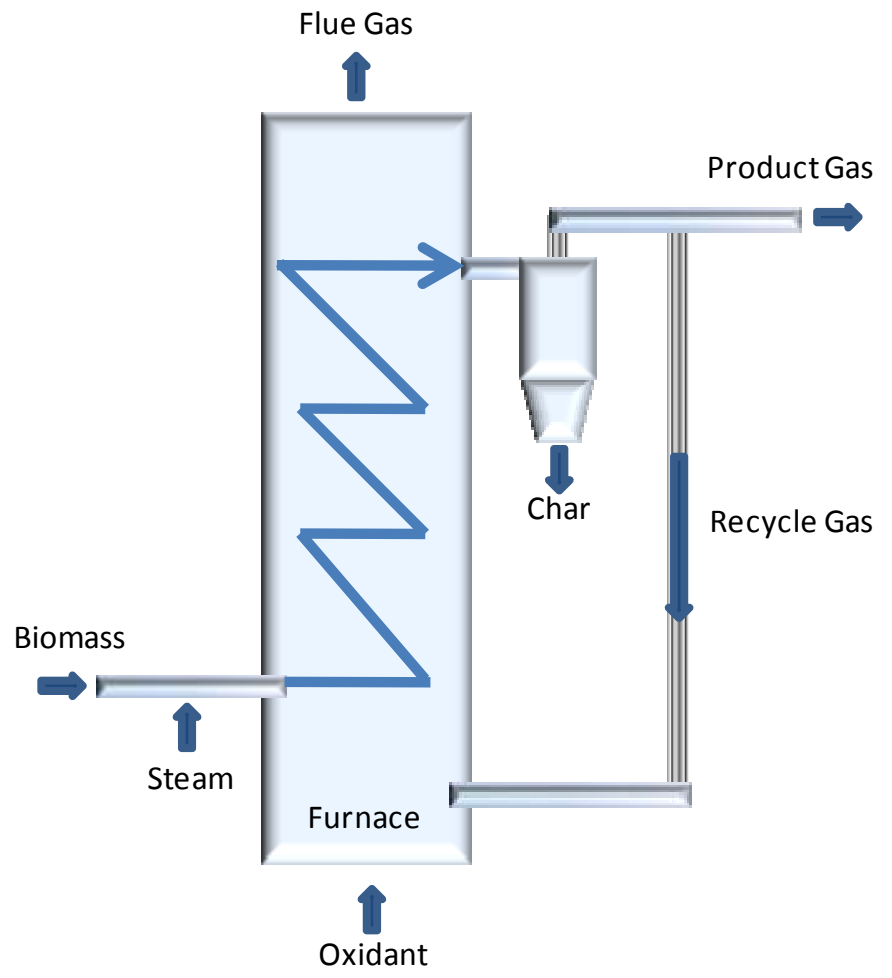

Figure 5.5. Simplified Schematic of an Entrained Flow Gasifier 


\subsection{Plasma Gasifiers}

Plasma gasifiers are characterized by the use of plasma, a low-density ionized vapor, to heat the feed stream. Air, nitrogen, argon, carbon dioxide, and steam may be used as the plasma gas. Feedstock materials are treated using extremely high temperatures $\left(1700^{\circ} \mathrm{F}-35,530^{\circ} \mathrm{F}\right)$ that convert solid or liquid fuel streams into synthesis gas and vitrified slag. In general, thermal plasmas may be generated by either an electric arc or by a radio frequency induction discharge. Arc plasmas are typically used for waste treatment because they are relatively insensitive to changes in process conditions. Further reaction may be enabled by a molten metal or glass layer. This configuration is referred to as a plasma melter. Plasma gasifier technologies are considered to be well established, particularly for vitrification of incinerator ash. Electric power requirements for treating waste ${ }^{1}$ have been reported in the range of 0.34-4.4 MM Btu per ton of waste (Heberlein and Murphy 2008). Figure 5.6 shows a simple illustration of a plasma gasifier.

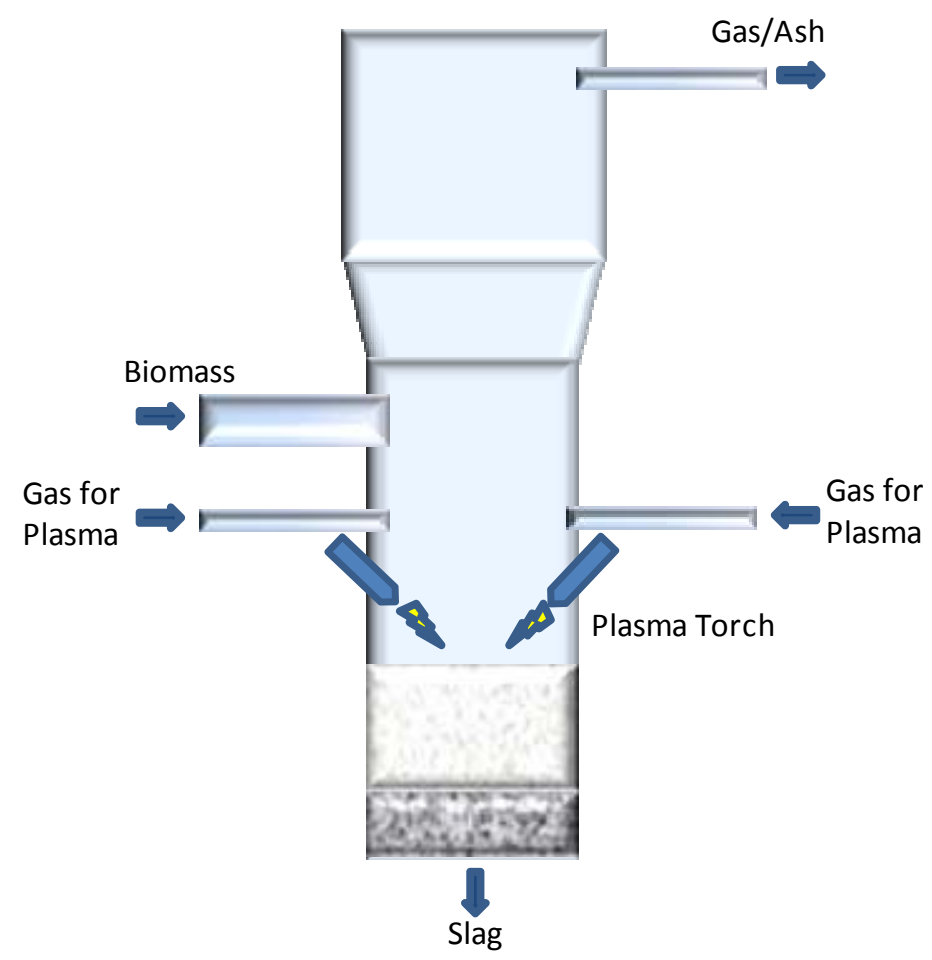

Figure 5.6. Simplified Schematic of a Plasma Gasifier

\footnotetext{
${ }^{1}$ Electric power requirements for treating auto shredder waste, fly ash, medical waste, and municipal solid waste with varying levels of pre-treatment (leading to the wide range in values given) have been reported.
} 


\subsection{Current State of MSW Gasfiers}

Gasifiers currently using MSW feedstocks are shown in Table 6.1. Information compiled in this table is based on information available in the literature (New York City 2008, Los Angeles County 2005, Westinghouse Plasma Corporation 2007, 2007a) and the gasifier sponsor's response to requests for information. The MSW gasifiers are grouped according to their status of development. Many of these designs are focused on producing heat and electric power and, consequently, are designed with close coupled combustion of the gases and using air as the oxidant in the gasification and combustion sections of the process. These designs would require modifications to the design or operation in order to produce a product gas suitable for liquid fuels synthesis. In a couple of cases, fuel gas or synthesis gas, for methanol synthesis is indicated. In these cases, minimal design changes would be expected. Coincidentally, those indicating methanol synthesis also operate in a manner where MSW is co-fed with coal.

\subsection{Commercial Gasifier Descriptions}

Four commercial gasifiers were identified that process MSW. These are described below.

\subsubsection{Westinghouse Plasma}

Westinghouse plasma torches were originally built for metallurgical applications. Westinghouse also builds a plasma gasification vitrification reactor system, which combines their torch with a moving bed. There are two commercial waste processing facilities and one commercial ash vitrification plant in Japan, all established between 1995 and 2002. One waste processing facility is a 242 short ton per day mixed auto shredder and MSW operation for power generation. The other is a 30 short ton per day mixed MSW and sewage sludge for heat production, which is then used in the waste water treatment facility (Westinghouse Plasma Corporation 2007). Westinghouse Plasma Corporation claims that capacities between 500 and 750 tons/day can be handled in a single reactor vessel (Westinghouse Plasma Corporation 2007a). The torch can be oxygen-blown and the company claims that it can make synthesis gas as a product (Westinghouse Plasma Corporation 2007a).

\subsubsection{Twin-Rec}

The Twin-Rec is a circulating fluidized bed system coupled with a slagging ash melter. MSW is shredded and screened to 12 inches or less and fed into the air-blown, fluidized bed gasifier, which contains a fluidizing medium (sand) and operates at $930^{\circ} \mathrm{F}-1200^{\circ} \mathrm{F}$ (Hotchkiss et al. 2002). Heavy inert material, such as glass, ceramics, and metals, as well as some of the ash, is extracted from the bed along with some of the sand. The sand is mechanically separated from the other materials and returned to the fluidized bed. Fine char, fly ash, and fuel gases, generated in the fluidized bed, carried over into the cyclonic melting chamber where the gases and char are combusted in air in a at $2,400^{\circ} \mathrm{F}-2,600^{\circ} \mathrm{F}$. The hot gases leaving the cyclonic melting chamber are fed into a boiler to produce steam for electricity generation and process heat. Molten slag leaving the bottom of the cyclonic melter chamber is quenched to form granules. Both the gasifier and melter operate at atmospheric pressure, without auxiliary fuel (except during start-up) or oxygen. The system requires a steam generator. The waste materials are converted to electricity and/or heat. Ebara (Ebara 2007) claims 14 commercial Twin-Rec facilities treating waste plastics, shredder residue, sludges, industrial waste and MSW. 
Table 6.1. MSW Gasifiers Currently in Operation

\begin{tabular}{|c|c|c|c|c|c|c|c|}
\hline Sponser & Gasifier & Type & Primary Feedstocks & Capacity (tpd) & Pretreatment & Products & $\begin{array}{c}\text { Gas } \\
\text { Treatment }\end{array}$ \\
\hline \multicolumn{8}{|c|}{ Commercial Scale } \\
\hline $\begin{array}{l}\text { Rigel Resource } \\
\text { Recovery }\end{array}$ & Westinghouse Plasma & Plasma & $\begin{array}{l}\text { MSW, specialty } \\
\quad \text { wastes }\end{array}$ & $72-300$ & Potential sizing & Power & Scrubbing \\
\hline Ebara & Twin-Rec & $\begin{array}{l}\text { Circulating fluidized bed + slagging } \\
\text { ash melter (both air blown) }\end{array}$ & $\begin{array}{l}\text { Auto shredder waste, } \\
\text { MSW, sewage sludge }\end{array}$ & $\begin{array}{l}462 \text { (modular, } 154 \\
\text { ea) }\end{array}$ & $\begin{array}{l}\text { Sizing to } 300 \\
\mathrm{~mm}\end{array}$ & Electricity, building materials & \\
\hline $\begin{array}{l}\text { Sekundarrohstoff- } \\
\text { Verwertungszentrum }\end{array}$ & Schwarze Pumpe & $\begin{array}{l}\mathrm{O}_{2} \text { blown entrained flow (GSP) + } \\
\text { slagging (BGL) + pressurized bed- } \\
\text { rotating grate (FDV-Lurgi) }\end{array}$ & $\begin{array}{l}\text { Lignite, tar oils and } \\
\text { waste }\end{array}$ & 2030 & $\begin{array}{l}\text { Sizing, } \\
\text { briquetting, } \\
\text { pelletizing }\end{array}$ & Fuel gas/methanol & Rectisol \\
\hline $\begin{array}{l}\text { Global Energy } \\
\text { solutions, LC }\end{array}$ & Thermal Converter & $\begin{array}{l}\text { 3-phase, 2-chamber downdraft: pre- } \\
\text { heated air }\left(400^{\circ} \mathrm{C}\right) \text {, primary } \\
\text { conversion }\left(1300^{\circ} \mathrm{C}\right) \text {, secondary } \\
\text { conversion in molten bed }\left(1675^{\circ} \mathrm{C}\right)\end{array}$ & MSW & 24-600 (modular) & None & Heat/power & \\
\hline \multicolumn{8}{|c|}{ Demonstration Scale } \\
\hline & High Temperature & & MSW co-fired With & & & & \\
\hline Krupp Uhde GmbH & Winkler & Fluidized bed $\left(\mathrm{O}_{2}\right.$, steam blown) & coal & 660 & Pelletizing & Methanol & \\
\hline $\begin{array}{l}\text { Interstate Waste } \\
\text { Technologies }\end{array}$ & Thermoselect & Closed-loop, high $\mathrm{T}, \mathrm{O}_{2} / \mathrm{NG}$ blown & MSW & $\begin{array}{l}\text { 110-792 (modular, } \\
\text { up to } 396 \text { tpd ea) }\end{array}$ & $\begin{array}{l}\text { Compaction, } \\
\text { degassing }\end{array}$ & Heat/power, liq fuels & $\begin{array}{l}\text { Quench, S, } \\
\text { heavy metal }\end{array}$ \\
\hline
\end{tabular}




\subsubsection{Schwarze Pumpe}

Schwarze Pumpe is a location in Germany that houses one of the largest German plants handling solid and liquid wastes including plastics, MSW, sewage sludge, shredder residues, oils, tars, and solvents. Sekundārrohstoff VerwertungsZentrum (SVZ) is a large scale operator of three types of gasifiers at the location - entrained flow (GSP), slagging (BGL), and rotating grate (FDV, Lurgi). The site opened in 1955 as a briquetting factory and power station. Schwarze Pumpe began generated town gas in the late 1960s. Their experience with MSW started in the mid-1990s with an emphasis on methanol production (Kamka and Jochmann 2005).

\subsubsection{Thermal Converter}

Global Energy Solution's Thermal Converter resembles a slagging, down-draft gasifier. MSW is shredded and screened to a lumped size no greater than a three inch cube. It has three distinct sections. Preheated air is introduced into the top of the fixed bed to heat and dry the MSW in the upper portion of the vessel. The middle section of the vessel is a rotated section where MSW is pryolyzed at temperatures ranging from $2,600^{\circ} \mathrm{F}-2,730^{\circ} \mathrm{F}$. In the lower section of the vessel, the inorganic fraction of the MSW is converted into a molten bed of slag that drips from the bottom of the vessel through an after-burner section and into a quench tank where the slag is cooled and solidified. Gases passing through the molten slag enter the after-burner where additional air is introduced to convert any remaining combustible gases. This zone reaches temperatures of $2,900^{\circ} \mathrm{F}$. Heat is recovered from the hot exhaust gases in a heat exchanger where inlet air is preheated and a recuperator where, presumably, steam can be produced for electric power generation and process heat. Preheated air for the gasifier can also be produced in the recuperator (Kamka and Jochmann 2005). This gasifier, as currently configured, is closely coupled with a combustion zone (afterburner) that precludes the production of a syngas, even if purified oxygen were to be used instead of air. The largest unit appears to have a capacity of about 75 tons/day.

\subsection{Demonstration Gasifier Descriptions}

Two demonstration-scale gasifiers were identified. These are described below.

\subsubsection{High Temperature Winkler Gasifier}

The High Temperature Winkler (HTW) plant in Berrenrath, Germany is commercial (for lignite) and has been in operation since 1986. Dried lignite, oxygen, and steam are fed to a fluidized bed reactor that operates at $145 \mathrm{psi}$ and $1750^{\circ} \mathrm{F}$. Product gas from the gasifier is cooled and cleaned in a ceramic candle filter and a water scrubber. Solid residues are combusted in an adjacent power plant. Dust collected from the filter is used in an adjacent wastewater treatment plant. The synthesis gas undergoes carbon monoxide conversion to obtain a hydrogen to carbon monoxide ratio suitable for methanol synthesis. Hydrogen sulfide and carbon dioxide are removed. The resulting syngas is sent to DEA Mineralol AG where it is synthesized into methanol. A series of tests were performed, using the HTW system, to successfully co-gasify RDF pellets (at rates up to $50 \%$ of the feed input) in 1998 . The demonstration was completed that year (Hotchkiss et al. 2002). 


\subsubsection{Thermoselect Gasifier}

The Thermoselect Gasifier handles raw MSW. The feedstock is preshredded to 20 inches or less, compressed into plug that is ram fed into a long degassing chamber that moves the MSW horizontally to the gasification chamber that is vertically oriented. Heat radiated from the gasification chamber slowly pyrolizes the compacted MSW as it slowly moves through the degassing chamber (approximately 1 to 1.5 hours solids residence time). Gases and vapors produced in the degassing chamber pass upwards through the gasification chamber where they are exposed to temperatures of approximately $2190^{\circ} \mathrm{F}$ for at least two seconds. Char and inorganic solids enter the gasification chamber and drop to its bottom, where the char and supplemental natural gas are combusted with purified oxygen producing temperatures as high as $3600^{\circ} \mathrm{F}$ causing the inorganic materials to form a molten slag. The molten slag, consisting of separate metal and mineral layers, is quenched in a water quench basin forming granules. The granules are sorted according to their properties to recover the metals. The product gas is quenched and cleaned in a multi-stage system in preparation for power generation or chemical synthesis (City of Los Angeles Department of Public Works 2005). Thermoselect's pilot plant was operated in Italy. There are 7 facilities in Japan, three of which handle MSW. The remaining 4 facilities gasify industrial waste. Two facilities export fuel gas. All facilities handling MSW use the fuel gas for gas engines. The MSW facilities use 2-3 lines to treat 120-300 tons per day (Thermoselect 2008). 


\subsection{Conclusions}

MSW is a potential gasifier feedstock that presents an opportunity to produce alternative liquid fuels because of its availablility in significant amounts at current landfills and because it is a predominantly biomass derived material that, like conventional biomass feedstocks such as wood, is a renewable resource. The viability of MSW as a gasifier feedstock for liquid fuels synthesis depends on several factors. Foremost is the availability of MSW in sufficient quantities to meet the minimum process scale required for economic feasibility. Based on this review, that process scale may be as large as 3,300 short tons per day of as received MSW, based on the anticipated scale required for conventional biomass feedstocks. However, the required scales for both types of feedstock depend on the cost of the feedstock, which has a significant effect on process economics. Conventional biomass feedstocks are market based and are a cost to the process, averaging nearly $\$ 45$ per dry short ton, whereas MSW is charged to the supplier as a tipping fee to dispose of the material. Historically, landfills receiving MSW and processing it to produce heat and energy using incinerators and gasifiers charge about $\$ 30$ per short ton (as received basis) additional fee beyond that typically charged to just landfill the material. The effect of the extra charges on process economics and, in turn, minimum process scale for economic feasibility needs to be further examined.

A review of available information on the number and size of various landfill sites around the country identified 47 sites that processed 3,300 short tons per day or more (as received basis) of MSW. Together these sites could potentially produce enough liquid fuel to meet approximately $1.4 \%$ of current transportation fuel demand (about $113 \mathrm{MM} \mathrm{bbl} /$ year of liquid fuel). A greater contribution could be attained if smaller scale facilities are found to be feasible due to latitude in the tipping fee charged to MSW producers.

Another important issue deals with the quality of MSW as a feedstock. MSW is a heterogeneous feedstock containing materials with widely varying sizes, shapes, and composition, which can lead to variable gasification behavior if used in an as received condition. It is expected that some minimal size reduction and sorting will need to be performed to make MSW suitable as a feedstock for MSW gasifiers. $\mathrm{RDF}$ is a processed form of MSW where significant size reduction, screening, sorting and, in some cases, pelletization is performed to improve the handling characteristics and composition of the material to be fed to a gasifier. There is a trade-off between the increased costs of producing RDF from MSW and potential cost reductions in gasifier design and operation.

The chemical make-up of MSW includes significant quantities of chemical constituents that can create problems in downstream processes. While the concentrations of these contaminants are greater than those found in conventional biomass feedstocks, they are roughly comparable to those found in coal. The commercial operation of 2 gasifiers co-feeding coal and MSW for methanol synthesis suggests that gas cleanup to remove key contaminants can be accomplished with existing technology.

This study identified four commercially available MSW gasifiers and two demonstration gasifiers. Three of these gasifiers produce only electricity and process heat so they are closely coupled to combustors. Consequently, they would require some design changes to be adapted to producing a synthesis gas. The commercial and demonstration gasifiers are currently available in sizes that range from 24 to 660 short tons per day MSW processing capability and will likely require multiple gasifiers to meet the minimum processing scale requirement for a liquid fuels synthesis plant. Further investigation is 
needed to determine the trade-offs between using many relatively small scale gasifiers that may be built as packaged systems or a few larger field erected gasifiers to minimize gasifier capital and operating costs. In addition, there are a large number of gasifier designs with a range of capacities that are at the pilot scale level of development. These were not examined closely and may ultimately be suitable for syngas applications.

Overall, this study concludes that MSW should be considered as a potentially viable gasifier feedstock for liquid fuels synthesis. A review of feedstock availability, composition, and handling characteristics, along with commercially available MSW specific gasifiers, did not identify any obvious insurmountable technical or economic barriers to commercialization. However, further research into the economic issues surrounding tipping fees and process scale is needed to verify economic viability and the appropriate plant scale for economic viability. 


\subsection{References}

340-04-005. 2004. Statewide Waste Characterization Study. California Integrated Waste Management Board. Sacramento, California.

40 CFR Part 257. Criteria for Classification of Solid Waste Disposal Facilities and Practices

40 CFR Part 258. Criteria for Municipal solid Waste Landfills

California Biomass Collaborative. 2006. An Assessment of Biomass Resources in California, 2006.

Department of Biological \& Agricultural Engineering, University of California. Davis, California.

California Biomass Collaborative. 2007. Municipal Wastes-Background Discussion Paper. Williams RB. Department of Biological \& Agricultural Engineering, University of California. Davis, California.

Caputo A C and P M Pelagagge. 2002. "RDF Production Plants: I Design and Costs." Applied Thermal Engineering. Vol. 22, Issue 4. Pages 423-437. Elsevier Inc., Burlington, Massachusetts. Accessed June 27, 2008 at http://dx.doi.org/ 10.1016/S1359-4311(01)00100-4.

Ciferno JP and JJ Marano. 2002. Benchmarking Biomass Gasification Technologies for Fuels, Chemicals, and Hydrogen Production. $\mathrm{E}^{2} \mathrm{~S}$ for National Energy Technology Laboratory.

City of Los Angeles Department of Public Works. 2005. Appendix E, Supplier Evaluations, in Evaluation of Alternative Solid Waste Processing Technologies. Prepared by URS Corporation for the City of Los Angeles Department of Public Works. Los Angeles, California. Accessed September 29,2008 at http://www.lacity.org/san/solid_resources/strategic_programs/alternative_tech/PDF/final_report.pdf

Cobb J. 2007. Production of Synthesis Gas by Biomass Gasification -A Tutorial. 2007 AIChE Spring National Meeting. April 22-26, 2007.

DOE/EIA-0383. 2008. Annual Energy Outlook 2008. Energy Information Administration, US Department of Energy, Office of Integrated Analysis and Forecasting. Washington, District of Columbia.

Ebara. 2007. TwinRec - Fluidized Bed Gasification and Ash Melting. Ebara. Zurich, Switzerland. Accessed September 18, 2008 at http://www.ebara.ch/_en_/twinrec.php?n=1.

Ecology. 2006. Solid Waste In Washington State $14^{\text {th }}$ Annual Report. Solid Waste and Financial Assistance Program, Washington State Department of Ecology. Olympia, Washington.

Ecology. 2008. Solid Waste and Recycling Data. Washington State Department of Ecology. Olympia, Washington. Accessed May 13, 2008 at http://www.ecy.wa.gov/programs/swfa/solidwastedata/.

Ecology. 2008a. "Tipping Fees at MSW Landfills." Solid Waste and Recycling Data. Washington State Department of Ecology. Solid Waste and Financial Assistance Program. Olympia, Washington. Accessed June 27, 2008 at http://www.ecy.wa.gov/programs/swfa/solidwastedata/disposal/TippingFees.xls. 
EPA. 2007. Municipal Solid Waste in the United States: 2006 Facts and Figures. Office of Solid Waste (5306P), US Environmental Protection Agency. Washington, DC.

EPA. 2008. MSW Characterization Methodology. Office of Solid Waste (5306P), United States Environmental Protection Agency. Washington, District of Columbia. Accessed June 13, 2008 at http://www.epa.gov/epaoswer/non-hw/muncpl/pubs/06numbers.pdf

EPA-530-F-07-030. 2007. Municipal Solid Waste in the United States: Facts and Figures for 2006. Office of Solid Waste (5306P), United States Environmental Protection Agency. Washington, District of Columbia.

EPA-530-R-95-023. 1995. Decision-maker's Guide to Solid Waste Management $2^{\text {nd }}$ Edition. Office of Solid Waste, RCRA Information Center (5305W), United States Environmental Protection Agency. Washington, District of Columbia.

EPA-530-R-95-008. 1995. Flow Controls and Municipal Solid Waste. Office of Solid Waste, Municipal and Industrial Solid Waste Division, United States Environmental Protection Agency. Washington, District of Columbia.

EPA-530-R-99-009. 1999. Biosolids Generation, Use, and Disposal in The United States, Solid Waste and Emergency Response (5306W), United States Environmental Protection Agency. Washington, District of Columbia.

EPA-530-R-99-013. 1999. Cutting the Waste Stream in Half: Community Record-Setters Show How. Solid Waste and Emergency Response (5306W), United States Environmental Protection Agency. Washington, District of Columbia.

EPA-530-R-99-016. 1999. Organic Materials Management Strategies. Solid Waste and Emergency Response (5306W), United States Environmental Protection Agency. Washington, District of Columbia.

EPA-832-R-06-005. 2006. Emerging Technologies for Biosolids Management. Office of Wastewater Management, United States Environmental Protection Agency. Washington, District of Columbia.

Florida Department of Environmental Protection. 1999. "Chapter 4: Landfill Disposal,” 1999 Solid Waste Management Annual Report. Bureau of Solid \& Hazardous Waste, Division of Waste Management, Florida Department of Environmental Protection. Tallahassee, Florida.

Franklin Associates. 2008. Integrated Solid Waste Management and Planning. Accessed 13 June 2008 at http://www.fal.com/solidwaste.htm.

Gasification Technologies Council. 2008. "State of the Gasification Industry," What is Gasification? Gasification Technologies Council. Arlington, Virginia. Accessed August 12, 2008 at http://www.gasification.org/what_is_gasification/state-of-gasification.aspx.

Heberlein J and A B Murphy. 2008. “Thermal Plasma Waste Treatment.” Journal of Physics D: Applied Physics Vol. 41, Issue 3. Institute of Physics. Bristol, United Kingdom. 
Hotchkiss R, W Livingston, and M Hall. 2002. Waste/Biomass Co-Gasification with Coal. Report No. COAL R216. DTI/Pub URN 02/867. Cleaner Coal Technology Transfer Programme, Department of Trade and Industry, United Kingdom.

Interior. 2008. "Population Density 2000 Map," National Atlas of the United States. United States Department of the Interior. Washington, District of Columbia. Accessed 28 July 2008 at: http://nationalatlas.gov/natlas/Natlasstart.asp.

Kamka F and A Jochmann. 2005. Development Status of BGL Gasification. International Freiberg Conference on IGCC \& XtL Technologies.

Klass DL. 1998. Biomass for Renewable Energy, Fuels, and Chemicals. Academic Press, A division of Elsevier Inc. Burlington, Massachusetts.

Los Angeles County. 2005. Conversion Technology Evaluation Report. URS Corporation for the Alternative Technology Advisory Subcommittee, Los Angeles County Integrated Waste Management Task Force. Los Angeles, California.

New York City. 2008. "Phase I: Evaluation of New and Emerging Solid Waste Management Technologies." Evaluation of New and Emerging Waste Management and Recycling Technologies and Approaches. Economic Development Corporation and Department of Sanitation. New York, New York.

NREL/TP-421-7501. 1994. Review and Analysis of the 1980-1989 Biomass Thermochemical Conversion Program. Stevens DJ. National Renewable Energy Laboratory. Golden, Colorado.

NREL/TP-431-4988A. 1992. Data Summary of Municipal Solid Waste Management Alternatives; Volume I. SRI International for National Renewable Energy Laboratory. Golden, Colorado. Accessed June 27, 2008 at http://lists.p2pays.org/ref/11/10516/.

NREL/TP-431-4988A.1. 1992. "Refuse-Derived Fuel.” Data Summary of Municipal Solid Waste Management Alternatives; Volume I. SRI International for National Renewable Energy Laboratory. Golden, Colorado. Accessed June 27, 2008 at http://www.p2pays.org/ref/11/10516/refuse.html.

NREL/TP-570-25357. 1998. Biomass Gasifier “Tars”: Their Nature, Formation, and Conversion.National Renewable Energy Laboratory. Golden, Colorado.

O’Leary P and P Walsh. 2002. Landfill Continuing Education Course. Waste Age magazine, Penton Media, Inc. New York, New York. and University of Wisconsin-Madison, Solid and Hazardous Waste Education Center. Madison, Wisconson. Accessed at http://landfill-ed.wasteage.com.

PB-293165. 1979. Recovery, Processing and Utilization of Gas from Sanitary Landfills. R Ham, K Hekimian, S Katten, W Lockman, and R Lofy. Lockman and Associates. Monterey Park, California.

Phyllis, Composition of Biomass and Waste Database. Energy research Centre of the Netherlands. Petten, Holland, Netherlands. Accessed April 24, 2008 at http://www.ecn.nl/phyllis.

Repa E. 2005. NSWMA’s 2005 Tip Fee Survey. National Solid Wastes Management Association. Washington, D.C. 
Rezaiyan J. and NP Cherenmisinoff. 2005. Gasification Technologies A primer for Engineers and Scientists. CRC Press. Boca Raton, Florida.

Simmons P, G Goldstein, S Kaufman, N Themelis, and J Thompson. 2006. The State of Garbage in America. BioCycle. 47(4): p. 26.

Simmons P, G Goldstein, S Kaufman, N Themelis, and J Thompson. 2006a. The State of Garbage in America Recycling Data Analysis. BioCycle 47(10): p. 21.

Stevens D. 1994. Review and Analysis of the 1980-1989 Biomass Thermochemical Conversion Program. NREL/TP-421-7501. National Renewable Energy Laboratory. Golden, Colorado.

Stiles D, S Jones, R Orth, B Saffell, D Stevens, and Y Zhu. 2008. Biofuels in Oregon and Washington: A Business Case Analysis of Opportunities and Challenges. PNNL-17351. Pacific Northwest National Laboratory, Richland, Washington.

SWIS. 2008. Solid Waste Information System. California Integrated Waste Management Board. Sacramento, California. Accessed May 5, 2008 at http://www.ciwmb.ca.gov/SWIS/Downloads/SWIS.xls.

Themelis N, Y Kim, and M Brady. 2002. Energy recovery from New York City solid wastes. ISWA Journal: Waste Management and Research 20(2002) p. 223-233.

Thermoselect. 2008. Projects in Japan. THERMOSELECT S.A. Locarno, Switzerland. Accessed September 26,2008 at http://www.thermoselect.com/index.cfm?fuseaction=spezific\&m=3.

Westinghouse Plasma Corporation. 2007. Projects Overview. Madison, Pennsylvania. Accessed September 18, 2008 at http://www.westinghouse-plasma.com/projects/overview.php

Westinghouse Plasma Corporation. 2007a. Plasma Gasification Vitrification Reactor. Madison, Pennsylvania. Accessed September 18, 2008 at http://www.westinghouseplasma.com/markets_applications/energy_production.php 


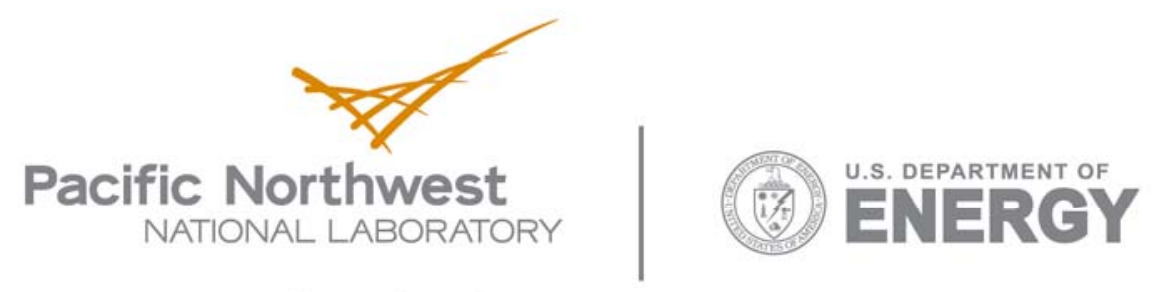

902 Battelle Boulevard

P.O. Box 999

Richland, WA 99352

1-888-375-PNNL (7665)

www.pnl.gov 